upf. $\begin{array}{ll}\text { Universitat } \\ \text { Pompeu Fabra } \\ \text { Barcelona }\end{array} \quad \begin{aligned} & \text { Department } \\ & \text { of Economics and Business }\end{aligned}$

Economics Working Paper Series

Working Paper No. 1565

\title{
Monetary policy at work: security and credit application registers evidence
}

José-Luis Peydró, Andrea Polo and Enrico Sette 


\title{
Monetary Policy at Work: Security and Credit Application Registers Evidence
}

\author{
José-Luis Peydró Andrea Polo Enrico Sette*
}

\begin{abstract}
The potency of the bank lending channel of monetary policy may be limited if banks rebalance their portfolios towards securities, e.g. to pursue risk-shifting or liquidity hoarding. To test for the bank lending and risk-taking (reach-for-yield) channels, we therefore analyze banks' securities trading, in addition to credit supply, in turn allowing us to also study the empirical relevance of key financial frictions. For identification, since the creation of the euro, we exploit the security and credit application registers owned by the central bank of Italy. In crisis times, we find that, with softer monetary policy, less capitalized banks prefer buying securities rather than increasing credit supply (not due to lack of good loan applications), thereby impacting firm-level real outcomes. Moreover, more - not less - capitalized banks reach-for-yield, which is inconsistent with the risk-shifting hypothesis. Results suggest that the main drivers at work are access to liquidity and risk-bearing capacity, and not regulatory capital arbitrage. Finally, in pre-crisis times, when financial frictions are limited, less capitalized banks do not expand securities holdings over credit supply.
\end{abstract}

Keywords: monetary policy, securities, loan applications, bank capital, reach-for-yield, held to maturity, available for sale, trading book, haircuts, regulatory arbitrage, sovereign debt.

JEL Codes: E51, E52, E58, G01, G21.

\footnotetext{
* José-Luis Peydró: ICREA-Universitat Pompeu Fabra, Imperial College, CREI, Barcelona GSE and CEPR, jose.peydró@upf.edu; Andrea Polo: Universitat Pompeu Fabra, Barcelona GSE and CEPR, andrea.polo@upf.edu; Enrico Sette: Bank of Italy, enrico.sette@bancaditalia.it (contact author). This draft is from April 2017. We thank Carlo Altavilla, Patrick Bolton, Douglas Diamond, Martin Brown, Christian Eufinger, Mark Flannery, Jordi Galí, Emilia Garcia Appendini, Nicola Gennaioli, Raj Iyer, Peter DeMarzo, Frederic Malherbe, David Martinez-Miera, Marco Pagano, Daniel Paravisini, Huw Pill, Soledad Martinez Peria, Ricardo Reis, Stefano Rossi, Tano Santos, Glenn Schepens Martin Schmalz, Andrea Sironi, Sasha Steffen, Sylvana Tenreyro, Annette Vissing-Jorgensen, Xavier Vives and seminar and conference participants at Berkeley, Stanford, Copenhagen Business School, Univeristy of Copenhagen, CREI, Zurich, LSE, Bocconi, Cattolica Milan, IESE, ECB, the Barcelona GSE Summer Forum, St. Gallen, Sciences Po-Banque de FranceBank of England "Empirical Monetary Economics Workshop", the ECB conferences on "Non-Standard Monetary Policy Measures" and on "Monetary Policy Pass-Through and Credit Markets" and the DNB-CEPR Conference on "Bank Equity over the Cycle" for helpful comments and suggestions. The views of this paper are those of the authors and do not represent the views of Banca d'Italia or of the Eurosystem. This paper has been developed through CEPR's Restarting European Long-Term Investment Finance (RELTIF) Programme, which is funded by Emittenti Titoli. Peydró acknowledges financial support from ECO2015-68182P (MINECO/FEDER, UE) and from the European Research Council Grant (project 648398).
} 
"With an impaired bank lending channel, monetary policy may lose its handle on the real economy." Mario Draghi, President of the European Central Bank (2014)

\section{Introduction}

Central banks have massively expanded their balance sheet since 2008, with main monetary rates around zero. However, the large injection of liquidity to banks may not have reached the real sector by means of expanded supply of credit. ${ }^{1}$ The potency of the bank lending channel of monetary policy may be limited if banks rebalance their portfolio towards securities holdings, e.g. to pursue liquidity hoarding or risk-shifting, as opposed to lending. For instance, in the words of Jeremy Stein (2013), Governor of the Federal Reserve Board: “ $A$ credit crunch may arise as other financial intermediaries (e.g., banks) withdraw capital from lending, so as to exploit the now-more-attractive returns to buying up fire-sold assets. Ultimately, it is the risk of this credit contraction, and its implications for economic activity more broadly, that may be the most compelling basis for regulatory intervention." Moreover, especially as central banks expand liquidity, less capitalized banks in Europe took on risky GIIPS sovereign debt; Acharya and Steffen (2015) argue that this evidence is consistent with risk-shifting, an excessive bank risk-taking via a carry trade.

To understand how monetary policy works via banks, including its possible limitations, and to test for the bank lending and risk-taking channels of monetary policy, therefore, it is crucial to analyze both securities trading by banks and the supply of bank credit to the real sector. Securities holdings by banks are a sizable fraction of their balance sheets, around $20 \%$ of assets in the US and Europe (e.g. in Germany and Italy), and several recent policy initiatives aim at limiting security trading by banks (Volker Rule in Dodd-Frank in the US, Likaanen Report in EU and Vickers' report in the UK).

A portfolio rebalance towards securities in crises may be the consequence of a credit demand problem, with few lending opportunities (Summers, 2014) and with risky, highly leveraged borrowers (Rogoff, 2015). At the same time, the low level of bank capitalization (Admati and Hellwig, 2013) can contribute to the impairment of the transmission of monetary policy to credit supply: banks, especially less capitalized ones, may e.g. decide to hoard liquid securities rather than issue relatively illiquid loans to SMEs.

\footnotetext{
${ }^{1}$ In most countries around the world, banks are not only the core, but - quantitatively - the largest part of the financial system. Regarding Europe, which is bank-dominated, for example, the ECB's Chief Economist, Peter Praet (2016), argues that: "This crucial role of the banking system explains why many of our monetary policy interventions during the crisis were aimed at repairing the bank lending channel."
} 
Monetary policy may also have unintended consequences in terms of financial stability, e.g. Draghi (2015) argues that: "Our monetary policy measures are necessary to achieve our primary objective of maintaining price stability. But we are nevertheless aware that they may have unintended side effects on the financial system." Low interest rates have been suggested as a driver of reach-for-yield, which may have contributed to amplify the credit cycle leading to the 2008 financial crisis (Allen and Rogoff, 2011; Rajan, 2005; Taylor, 2008; Stein, 2013), consistently with a risk-taking channel of monetary policy (Adrian and Shin, 2011; Borio and Zhu, 2008). Loan level data support this view prior to the crisis (Jiménez, Ongena, Peydró and Saurina, 2014). Yet, in crisis times, risk-shifting incentives may be stronger, notably for less capitalized banks (Tirol, 2006; Freixas and Rochet, 2008), which, in the face of the huge expansion of central banks' balance sheets, may have reached-for-yield more easily, quickly, by adjusting their securities holdings. Previous evidence, in part because of lack of data, has entirely focused on analyzing GIIPS sovereign debt, which indeed became risky during the crisis, and on the sovereign-bank nexus (Acharya and Steffen, 2015; Brunnermeier, Garicano, Lane, Pagano, Reis, Santos, Thesmar, Van Nieuwerburgh and Vayanos, 2016); however, GIIPS non-sovereign securities and loans to firms may be riskier, offering higher yields, and are quantitatively more important (Bocola, 2016). On the other hand, increasing credit supply to firms with higher yield and risk, which are more financially constrained, especially in crisis times, may be a desired monetary policy outcome (Gertler and Gilchrist, 1994).

In this paper, we test the bank lending and risk-taking (reach-for-yield) channels of monetary policy (see e.g. Bernanke and Blinder, 1988, 1992; Kashyap and Stein, 2000; Bernanke, 2007; Adrian and Shin, 2011) by analyzing banks' securities trading in addition to credit supply. ${ }^{2}$ In particular, we address the following questions. Does softer monetary policy encourage less capitalized banks to increase their holdings of securities during crises? Are the effects stronger for security holdings than for credit supply? If less capitalized banks prefer holding more securities than expanding the supply of credit to the real sector, ${ }^{3}$ is it because of lack of good borrowers in loan applications? Are there firm-level real effects associated? Which banks take on higher yield via securities, those with less, or more, capital? Do banks also reach-for-yield in lending? What are the differences in normal versus crisis times?

\footnotetext{
${ }^{2}$ Theory also links bank lending and securities trading. E.g., Shleifer and Vishny (2010) show that fire sales in securities in crises make banks prefer buying securities than lending to firms; Diamond and Rajan (2011) show that fire sales leads to a credit freeze as banks hoard on liquidity to buy the securities in the near future.

${ }^{3}$ We also analyze whether security trading is related to non-financial corporate debt and find that the amount of these securities in the balance sheets of Italian banks is less than $1 \%$ of bank loans to firms. This number is also low in other bank-dominated countries, and small and medium size firms (SMEs) are in general financially constrained, with lack of market access and strong bank dependence even in non-bank dominated countries (see e.g. Allen, Chui and Maddaloni, 2004).
} 
Our analysis of the bank lending and risk-taking channels of monetary policy is not only necessary to evaluate the transmission channel of a key public policy, but it also allows testing for the empirical relevance of key financial frictions and channels used in finance models (Tirole, 2006; Allen and Gale, 2007; Freixas and Rochet, 2008; Freixas, Laeven and Peydró, 2015). Our analysis sheds light on: (i) risk-shifting due to low capital (also called gambling for resurrection or asset-substitution); (ii) credit crunches due to low bank capital, as less capitalized banks are more liquidity-constrained and thus may buy securities with low haircuts and short maturity which tend to be more liquid; (iii) regulatory capital arbitrage to minimize bank capital requirements; (iv) risk-bearing capacity depending on bank accounting and regulation on held to maturity versus available for sale and trading portfolios.

For empirical identification, we exploit the security and credit application registers owned by the central bank of Italy in its role of bank supervisor, at monthly frequency since the creation of the euro in 1999. The security register contains - at the security (ISIN) level data - all securities investments for each bank in Italy (not just government bonds, or just securities that banks pledge as collateral to borrow from the ECB). We analyze bonds ( $81 \%$ of holdings), and, for each security, we obtain yields, issuer, rating, haircuts applied by the ECB in repo loans, prices and remaining maturity. The granularity of our data allows us to observe, even within an issuer (say the Italian sovereign), all the different securities with different yields, maturities, haircuts held by banks every month. In addition, the credit and firm registers allow us to observe loan applications, ex-ante loan default probabilities and rates, which allow to identify the supply of bank credit, including banks' risk-taking incentives.

We analyze the data at the security-bank-month and at the (firm)application-bank-month level, since this allows us: (1) to test, as monetary policy becomes softer, whether banks with different characteristics change their holdings of securities with different ex-ante yields, as well as different haircuts, maturity, ratings and capital weights, or lend more to firms with different ex-ante loan rates and default probabilities proxied by z-scores; (2) to control for key unobservables in some regressions via security*time and firm*time fixed effects. Security*time fixed effects help us to control - in each month - for how much of each security is issued and outstanding, fully controlling also for unobserved time-varying risk at the security level (ratings, price or maturity), thus isolating the demand of securities by banks. When we analyze loan applications, we include firm*time fixed effects in the regressions, which implies that we analyze the granting of loan applications by different banks to the same firm in the same period, thus fully controlling for unobserved and observed time-varying borrower fundamentals in loan applications, thereby identifying credit supply. 
As far as we are aware, ours is the first paper using a comprehensive security register for banks and a credit register with loan applications and rates; this is especially important in a bank dominated economy where banks are the main providers of finance to corporations and are also key players in security markets. We match the registers with supervisory bank-level balance sheet information and exploit bank capital heterogeneity controlling for other bank variables. The bank capital ratio is a sharp measure for both the intensity of the agency conflicts between bank shareholders and their financiers (including depositors, debtholders and tax payers) and the strength (net-worth) of bank balance sheets, and hence capital is crucial for both the risk-taking and bank lending channels respectively (Holmstrom and Tirole, 1997; Bernanke, 2007; Freixas and Rochet, 2008; Adrian and Shin, 2011).

Moreover, we also match the data with the official balance sheet data deposited by firms to the Chambers of Commerce, as required by the Italian law, to obtain a measure of ex-ante default probability for the analysis of the risk-taking channel of monetary policy, and also to analyze firm-level real effects associated with the bank lending and risk-taking channels of monetary policy, in particular - apart from analyzing firm-level total credit - we analyze firmlevel investment, the wage bill and sales, which are key determinants of aggregate output (GDP). We also match the data with the Bank of Italy Survey of Industrial and Service Firms (SISF) which provides detailed information on firm expected demand.

We focus on the crisis period, as financial frictions are then strong and thus substitution between securities and loans may be more prevalent (Shleifer and Vishny, 2010; Diamond and Rajan, 2011). We exploit the unconventional monetary policy measures taken by the ECB after the Lehman default, which we proxy by the size of the balance sheet of the ECB (subtracting the autonomous factors that are beyond ECB's direct control), deflated by the Italian nominal GDP. This measure proxies for the series of unconventional monetary policies undertaken by the ECB that provided liquidity after the start of the financial crisis in September 2008 (main refinancing operations (MRO) with fixed rate full allotment, different long-term refinancing operations (LTRO), buying of different securities as for example the Security Market Programme and Covered Bonds Purchase Programme, and others). We control for other macro variables, including time fixed effects, and interactions of key bank, security and loan variables with the forecast of future economic activity and financial uncertainty, among other variables. We also look at alternative measures of monetary policy by using shadow rates (Wu and Xia, 2017) or analyzing just the largest quantitative policy changes (the two initial 3-year LTROs on December 21, 2011 and February 29, 2012). We also study conventional monetary policy in the pre-crisis period (January 1999 to August 
2008), where we proxy monetary conditions by a measure related to Taylor-shocks (Euro area overnight rates cleaned by Italian GDP and consumer price growth).

In crisis times, we find robust evidence that, with softer monetary policy, less capitalized banks prefer buying securities rather than increasing credit supply (and these results are not due to lack of good loan applications to less capitalized banks). In particular, we find that banks with less (compared to more) capital expand more into securities when the ECB provides higher liquidity via expanding its balance sheet, whereas the opposite happens on the supply of credit to firms - banks with less (compared to more) capital grant less loan applications to the same firm in the same quarter. ${ }^{4}$ Results are identical if we exclude securities to Italian non-financial firms (which are tiny) or are very similar if we only analyze foreign issued securities (which are not directly supporting the Italian economy). Moreover, the differential result on securities holdings versus lending is confirmed by aggregate bank level data with all securities and loans held by banks, where an increase in one standard deviation of the unconventional monetary policy variable makes banks in the 25-percentile of bank capital, as compared to the 75-percentile, increase securities holdings over lending with a semi-elasticity of 7.25 per cent. Differently, in pre-crisis (normal) times, when financial frictions are limited, as monetary policy becomes softer, less capitalized banks do not expand securities holdings over supply of credit to firms.

The differential result on securities versus lending during the crisis period translates into real effects at the firm level. After an increase in one standard deviation in unconventional monetary policy, firms exposed to banks with less capital (25 percentile), in comparison to firms exposed to banks with more capital (75 percentile), receive less credit overall, invest less, reduce the wage bill and decrease sales (the semi-elasticities are respectively 11 per cent, 10 per cent, 19 per cent and 11 per cent), controlling for a proxy of expected demand.

In sum, in crisis times, with softer monetary policy, less capitalized banks prefer buying securities rather than increasing credit supply, thereby impacting firm-level real effects. Less capitalized banks may prefer securities over credit in crisis times to have more liquid assets, to economize on regulatory capital, and/or to risk-shift with securities. Therefore, to further understand the different drivers of our results, and to also test for the risk-taking (reach-foryield) channel of monetary policy, we analyze heterogeneous effects across e.g. different yield, haircuts, maturity, capital risk weights, securities classes, such as government debt, and different portfolios, such as held to maturity versus available for sale and trading book.

\footnotetext{
${ }^{4}$ We also find that when monetary policy (conventional and unconventional) becomes softer, banks increase their holdings of securities. Results suggest that effects are moreover stronger for securities than for lending.
} 
We find robust evidence that more - not less - capitalized banks reach-for-yield in crisis times, when monetary policy is softer, which is against the risk-shifting hypothesis. ${ }^{5}$ In particular, more capitalized banks buy more securities with higher ex-ante yield (also after controlling for the correlation of securities traded with the existing bank portfolio), as the provision of central bank liquidity is higher (these results are robust to analyzing the same security in the same month or securities with the same rating and maturity in the same month). In addition, we do not find a differential risk-taking behavior in loan applications by banks of different capital in crisis times. Regarding economic effects, there is a $31 \%$ semi-elasticity of an increase in one standard deviation of unconventional monetary policy on the net purchases of securities; moreover, the increase in purchases of securities with lower yield (one standard deviation) by banks with low capital (25-percentile), with respect to banks with higher capital (75-percentile), after an increase in one standard deviation in unconventional monetary policy, is $30 \%$ of the average increase due to the softer monetary policy.

Importantly, the result on reach-for-yield in securities is confined to securities which are in the available for sale and trading portfolios, and not in the held to maturity ones. If a security is in the first two types of portfolios, the unrealized changes in fair value (e.g. losses in crisis times when security prices decline) are recognized in the income statement (trading portfolio) or in the comprehensive income (available for sale portfolio); however, this does not happen if a security is in the held to maturity portfolio. These findings suggest that less capitalized banks cannot afford to buy riskier securities in crisis times, as the potential reduction in security prices could further damage their already fragile balance sheet.

We also obtain identical reach-for-yield results when analyzing only Italian government bonds, hence pure regulatory capital arbitrage cannot explain the lower reach-for-yield by less capitalized banks, as all government bonds have zero risk weights. ${ }^{6}$

Less capitalized banks moreover buy more securities with lower (ECB) haircut (or lower yield or short maturity) that can be used to borrow at better conditions in repo loans, which suggest that access to liquidity is another key driver of the results. ${ }^{7}$

\footnotetext{
${ }^{5}$ The risk-shifting hypothesis implies stronger risk-taking by less capitalized banks. This relative testable prediction is what we analyze; our paper is silent whether, in absolute terms, less capitalized banks do take, or not, excessive risks, as these banks e.g. could buy only triple A securities (e.g. German sovereign debt). Moreover, we analyze risk-shifting associated with higher central bank liquidity, in particular whether less capitalized banks reach for higher yield when the central bank provides higher overall liquidity, controlling e.g. for the correlation of securities traded with the existing portfolio.

${ }^{6}$ Since we also obtain identical results in the overall sample analyzing securities with identical rating and maturity in each month, which determine the regulatory capital weights, our results are not explained by differences in regulatory capital risk weights.
} 
We contribute to the literature in two main ways. ${ }^{8}$ First, a large theoretical literature studies the transmission of monetary policy via banks (e.g., Bernanke and Blinder, 1988; Bernanke and Gertler, 1995; Stein, 1998; Diamond and Rajan, 2006 and 2012; Freixas and Bolton, 2006; Gertler and Kiyotaki, 2010; Freixas, Martin, and Skeie, 2011; Allen, Carletti, and Gale, 2014; Dell'Ariccia, Laeven and Marquez, 2014; Stiglitz, 2016; Coimbra and Rey, 2017; Martínez-Miera and Repullo, forthcoming), and there is evidence of the impact of monetary policy on only bank loans (e.g., Bernanke and Blinder, 1992; Kashyap and Stein, 2000; Jiménez, Ongena, Peydró and Saurina, 2012 and 2014). However, despite the fact that security holdings by banks are large, may affect credit supply, and there may be reach-foryield in banks' security holdings, as far as we are aware, there is no empirical evidence on the bank lending and risk-taking (reach-for-yield) channels of monetary policy analyzing banks' security trading, and its relation with credit supply. ${ }^{9}$

Our findings show that analyzing whether (and how) monetary policy affects banks' security trading is crucial (i) for credit supply and thus for the bank lending channel of monetary policy (Bernanke and Blinder, 1992; Bernanke and Gertler, 1995; Kashyap and Stein, 2000; Bernanke, 2007), and (ii) for reach-for-yield incentives and thus for the risktaking channel of monetary policy (Adrian and Shin, 2011). These latter results also shed light on the interactions between monetary and macroprudential policies, given the new responsibilities for the Fed and ECB on financial stability, which was historically a dominant concern for central banks (Bagehot, 1873; Stein, 2012).

\footnotetext{
${ }^{7}$ For liquidity, it may also be important to deposit excess reserves at the ECB; however, looking at data from the supervisory reports we find that this phenomenon is not economically large (the percentage of total reserves out of the total assets of banks on average during the crisis is 1.71 , but most of the reserves are required, with the excess reserves close to 0; e.g. in December 2013 the median of the percentage of excess reserves is only 0.02 per cent); nevertheless, the results of the paper are very similar if we include excess reserves at the ECB.

${ }^{8}$ Our findings also relate to the large literature on bank capital. Capital crunches can lead to credit crunches (as shown for example by Bernanke and Lown, 1991; Peek and Rosengren, 2000; and papers related to the last global financial crisis). Moreover, there is a macroprudential role of pro-cyclical capital regulation (countercyclical capital buffers) for smoothing credit cycles (Jiménez, Ongena, Peydró and Saurina, forthcoming). Our results show that - for banks with less capital - softer monetary policy in crisis times have stronger effects in securities trading than in the supply of credit to non-financial firms.

${ }^{9}$ A few contemporaneous papers use subsets of the security register. Crosignani, Faria-e-Castro and Fonseca (2016) look at the purchases of sovereign bonds by Portuguese banks around the 3-years LTRO. Carpinelli and Crosignani (2017) focus on lending by banks around the 3-year LTRO and use an aggregate measure of securities holdings, but they do not study security trading by banks. Abbassi, Iyer, Peydró and Tous (2016) use a comprehensive security register in Germany to analyze bank trading in fire-sold assets during the crisis, however they do not analyze monetary policy. For other intermediaries, Becker and Ivashina (2015) show evidence on reach-for-yield in bonds by insurance firms. For an analysis of US QE via banks, see Chakraborty, Goldstein and MacKinlay (2016), and via households, see Di Maggio, Kermani and Palmer (2016). Moreover, none of the above papers use loan applications.
} 
Second, our paper contributes to the recent literature on banks' investment behavior, in particular the increase in holdings of sovereign debt during the Euro area sovereign crisis, using EBA stress test data or bank-level data, from balance sheets or from the collateral pledged to borrow from the ECB (Acharya and Steffen, 2015; Horvath, Huizinga and Ioannidou, 2015; Drechsler, Drechsel, Marquez-Ibanez and Schnabl, 2016; Altavilla, Pagano and Simonelli, 2016). These works using Euro area data argue overall that securities purchases were driven by risk-shifting and by moral suasion by governments. We instead analyze only one country - Italy - but enlarge the dataset by (i) including all bonds purchased by banks (including non-sovereign bonds) and loans, which have on average higher yields than government bonds and are quantitatively more important; and by (ii) observing yields, haircuts, maturity, ratings for each security, even within a sovereign (or any other) issuer.

Our comprehensive datasets not only allow us for stronger identification but also for a more complete analysis, obtaining both new results and different interpretation of previous findings. We find that, when the ECB provides high liquidity, less capitalized banks buy more GIIPS (Italian) public debt. However, our results are not consistent with risk-shifting, as we also find that these banks (i) also buy more non-government bonds (including foreign bonds) with equal or higher intensity, and (ii) - within sovereign debt (and also in general) - buy securities with lower - not higher - yield. Overall, our results are more consistent with riskbearing capacity of banks (i.e., banks with more capital can afford to take on higher risk, see e.g. Adrian and Shin, 2011) and the importance of accessing liquidity in crisis times (i.e., banks with less capital have more liquidity needs, see e.g. Rochet and Vives, 2004); ${ }^{10}$ our results are on the other hand less consistent with regulatory capital arbitrage or risk-shifting. ${ }^{11}$

The rest of the paper is organized as follows. Section 2 describes the main datasets and explains the empirical strategy. Section 3 presents and discusses the results. Section 4 concludes, highlighting some implications for public policy and for finance-macro models.

\footnotetext{
${ }^{10}$ Our results are also related to the literature on sovereign risk and bank loans (see e.g. Gennaioli, Martin and Rossi, 2014).

${ }^{11}$ Moral suasion or financial repression does not seem fully consistent with the results, as banks with less capital also buy more securities that are non-(Italian)government bonds (with equal or higher intensity than Italian public debt); and they also buy with similar intensity foreign issued bonds. Though the literature uses explicit measures of government control such as state-owned banks or bailed-out banks for the moral suasion hypothesis, less capitalized banks are relatively closer to financial distress, thereby potentially needing more explicit and implicit guarantees by the government in a crisis, hence they can be more influenced (moral suasion/financial repression) by the government (a political economy hypothesis also made by Drechsler, Drechsel, MarquezIbanez and Schnabl (2016) who also focus on less capitalized banks). Recall, that our main variable in the paper is bank capital (not state-owned banks) since our main questions in this paper are about the bank lending channel (where capital proxies the strength of the bank balance sheets) and the risk-taking channels (where capital proxies the agency conflicts).
} 


\section{Data and Empirical Strategy}

In this section we describe the data and the empirical strategy, including the main variables used in the paper.

\subsection{Data}

We exploit the security and credit application registers owned by the central bank of Italy in its role of bank supervisor. We also match these datasets to bank, security and firm level data, and to macroeconomic variables, including monetary policy ones.

We have access to the Security Register, which is a supervisory centralized dataset managed by the Bank of Italy that includes microdata on all securities investments - at the security-level (ISIN code) - for each bank in Italy (bonds, ABS, equities, derivatives and shares of mutual funds) collected by the Bank of Italy in the Supervisory Reports. Data are available at monthly frequency from 1999, the first year of the common European monetary policy (the euro).

For each security, banks must report the notional amount they hold at the end of each period (stock of individual securities). We use the unique International Security Identification Number (ISIN) associated with every security to merge the data on holdings with: a) Datastream to obtain the monthly time series of prices and yields; b) FactSet to get additional information regarding the issuer, the residual maturity and the time series of ratings (in case of bonds); and c) the haircuts of marketable assets applied to each security in each point in time published online and updated weekly by the ECB. We compute the quantity of securities in banks' portfolio by dividing the notional amount by the market price at the corresponding date (banks are required by the regulation to report the market value of the securities they hold using the closing market price of the last working day of the month). This is crucial to control for changes in values which may be caused by changes in the policy rates.

We also have access to the complete Central Credit Register which is a supervisory, centralized dataset managed by the Bank of Italy that records the credit exposure of resident banks to non-financial firms. We have access to loan applications, volumes and rates. ${ }^{12} \mathrm{We}$ merge the credit register with the official balance sheet data deposited by non-financial firms

\footnotetext{
${ }^{12}$ In this paper we introduce the securities data. For a detailed explanation of the credit data in the Italian Credit Register, including the firm and bank level data, see Bofondi, Carpinelli and Sette (2017) or Ippolito, Peydró, Polo and Sette (2016). Note that neither of these papers analyze monetary policy.
} 
to the Chambers of Commerce (as required by the Italian law) ${ }^{13}$ to obtain firm-level probability of default as well as firm investment, wage bill and sales and with the Bank of Italy Survey of Industrial and Service Firms (SISF) to obtain additional information on firm expected demand. ${ }^{14}$ Finally, we use the Italian Supervisory Reports to obtain data on individual and consolidated balance sheets for banks in Italy.

As of 2013, the average bank has 59 per cent of its assets in credit (two thirds to firms and one third to households) and 17 per cent in securities. The composition of securities during the crisis period on average is the following: 81 per cent are bonds, out of which 58 per cent are issued by governments, 34 per cent by financial firms, 2 per cent by non-financial firms and 6 per cent by other entities (e.g. international organizations or municipalities); 9 per cent are Asset Backed Securities (ABS); 3 per cent are shares; and 7 per cent are other securities (e.g. shares of mutual funds, derivatives, covered and structured bonds).

We apply the following filters to the securities data. We consider only debt securities as they represent the large majority of securities and we can compare differential reach-for-yield by different banks in a class of very similar securities (as we do for loans); ${ }^{15}$ we exclude the holdings of bonds issued by the same bank or by a bank belonging to the same group, as incentives are different in these group of bonds. To reduce the influence of securities of small value, we drop those for which the total notional amount for the entire banking sector are below EUR 10 million and the securities for which the average notional amount across all periods of each bank is below EUR 10 thousands. The resulting set of securities comprises over $95 \%$ of the total holdings for which price data are available. We also exclude from the analysis banks with total assets below EUR 1 million and mutual banks, the latter being subject to specific capital regulation. The final sample consists of 1388 securities and 104 banks in the crisis period and of 815 securities and 120 banks in the pre-crisis period. All

\footnotetext{
${ }^{13}$ We retrieve the data from Cerved, which is a member of the European Committee of Central Balance-Sheet Data Offices.

${ }^{14}$ SISF is a panel representative survey administered to approximately 3,000 Italian firms (with at least 20 employees), designed to obtain firm-level information on firms' economic activity.

${ }^{15}$ We exclude derivatives and assets backed securities because these are mostly traded over the counter (OTC), hence we do not observe the market price and thus we cannot calculate a measure of net buys. However, a) the profits from trading in securities and the return on assets are positively correlated (which suggests that securities are not used to hedge the risks in the loan portfolio) while the profits from trading in securities and the profits from derivatives are not negatively correlated, thereby suggesting that banks do not use derivatives to hedge the higher risk they get in trading in securities; b) Italian banks have never been significantly exposed to ABS issued by countries with a real estate bubble (US, Spain, Ireland) (for the exposure to asset backed securities, see Bonaccorsi di Patti and Sette (2012) and BIS data, www.bis.org/statistics); c) our results are confirmed when we take out the largest banks which have a higher derivatives exposure. We also exclude two small banks, Ifis and Fonspa, which are specialized in non-performing loans.
} 
major banks operating in the country are included in our sample; we use the same sample of banks when we study lending.

\subsection{Empirical Strategy}

As argued in the Introduction, to test for the bank lending and risk-taking channels of monetary policy it is necessary to analyze banks' securities trading, in addition to lending. The potency of the bank lending channel of monetary policy may be limited if banks rebalance their portfolios towards securities and, in addition, banks can reach-for-yield with securities and hence securities impact the risk-taking channel of monetary policy. Moreover, securities holdings by banks are a sizable fraction of their balance sheets, around $20 \%$ of assets in the US and Europe, and there are several recent policy initiatives aiming at limiting security trading by banks across the Atlantic. As the literature has previously analyzed only loans, we put more emphasis in this paper on securities trading rather than lending, though we analyze both.

We focus on the crisis period, as financial frictions are then strong and thus substitution between securities and loans may be more prevalent (see, for example, Shleifer and Vishny, 2010; Diamond and Rajan, 2011). However, we also analyze the pre-crisis period (1999:M12008:M8) before the failure of Lehman Brothers on mid-September 2008. Specifically, we analyze whether and how banks modify securities holdings (or the granting of loan applications) depending on monetary policy conditions, bank, and security (or loan) characteristics (for the exact equations that we estimate, please see the results section). We analyze securities trading (and granting of loan applications) and are interested in the coefficient of the double interaction between monetary policy and bank capital (for the bank lending channel) and the triple interaction between monetary policy, bank capital and ex-ante security (or loan) yield or other measures of risk (for the risk-taking or reach-for-yield channel).

Instead of analyzing the data at the bank level as the literature does (see the references in the Introduction), we analyze the data at the security-bank-month and at the (firm) application-bank-month level. This is essential for studying heterogeneity, as different securities within a bank have different ex-ante yields, as well as different haircuts, maturity and capital weights, and as different loans to firms have different ex-ante loan rates and default probabilities. Note that even securities within the same issuer (even in the same time period) may have different yields, maturities, haircuts and ratings. Moreover, and crucially for identification, our micro-level data allow us to control for key unobservables, via 
security*time and firm*time fixed effects. Security*time fixed effects are a multiplication of a dummy for each security and a dummy for each month of each year (substantially stronger than adding just security and time fixed effects). They help us to control - in each month - for how much of each security is issued and outstanding (e.g. bonds of a particular security may mature), thus isolating the demand of securities by banks, and also to fully control for ratings, price or maturity, unobserved time-varying risk at the security level. For example, we can analyze the reach-for-yield of different banks controlling fully for time-varying ratings and maturity, the main determinants of the risk weights used to compute the regulatory capital ratios.

When we analyze the loan applications, we include firm*time fixed effects in the credit applications regressions, which implies that we analyze the granting of loan applications by different banks to the same firm in the same period, thus controlling for unobserved and observed time-varying borrower fundamentals in loan applications, thereby identifying credit supply. For loans, we look at quarters instead of months under the assumption that adjusting the loan portfolio to new monetary policy conditions requires more time than simply adjusting the securities portfolio (e.g. screening of opaque SMEs). In addition, as explained below in the results sections, we include other fixed effects and a battery of controls for robustness checks, including different level of clustering of standard errors. Finally, for robustness, we also analyze the results at the bank level, aggregating all the securities holdings and all loans for each bank.

For the security-bank-month level data, our main dependent variable is Trading of security $s$ by bank $b$ at time $t$ (month). We use the Davis-Haltiwanger definition (Davis and Haltiwanger, 1992) to include both the extensive and intensive margin. We define the following:

$$
\text { Trading }_{s, b, t}=\frac{\text { Holdings }_{s, b, t}-\text { Holdings }_{s, b, t-1}}{\frac{1}{2} *\left(\text { Holdings }_{s, b, t}+\text { Holdings }_{s, b, t-1}\right)}
$$

Trading $_{\mathrm{s}, \mathrm{b}, \mathrm{t}}$ is the increase in holdings of security $s$, by bank $b$ during the month $t$. This variable is symmetric around 0 and it lays in the closed interval $[-200,200]$ with final sales (initial purchases) corresponding to the left (right) endpoint. This measure facilitates the integrated treatment of initial purchases (passing from 0 to a positive number), final sales (passing from a positive number to 0 ) and continuing trading in the empirical analysis (see the Appendix for an exact definition on all the variables used). In Table 1 (which reports the descriptive statistics of the main variables used in the paper), we report that the average 
monthly Trading in the crisis period is 5.1. The median change is zero but there is a large standard deviation (79.7) which implies a huge heterogeneity in banks' securities trading. ${ }^{16}$

\section{TABLE 1 HERE}

For the (firm) application-bank-month level data, we analyze the granting of loan applications, where the dependent variable is a dummy variable that equals one if a loan application is granted to firm $i$ by bank $b$ over the quarter starting in month $t$, when the application was posted. In practice, if we observe a loan application, say, in January 2010, we define it as granted if we observe positive credit granted by the same bank which received the application to the corporate borrower posting the application (identified by the credit register unique identification number) in the same month (January) or in the next quarter (February, March, or April 2010). Table 1 shows that the average probability of obtaining at least a loan for a firm after applying to banks is around 40 per cent. In addition, when analyzing the aggregate bank level results, we use as the dependent variable the ratio of security holdings over total loans (we either give equal importance to each bank or more importance to the larger banks).

Finally, we also analyze firm-level outcomes to explore whether the bank lending channel of monetary policy has consequences in terms of investments, wage bill and sales. Since in the firm-level real effects regressions we cannot control for demand as in the loan level data, we control for growth opportunities by restricting the analysis to the firms included in the Bank of Italy Survey of Industrial and Service Firms (SISF) which provides direct information on firm expected demand. A crucial feature of SISF is that it contains a set of question that directly elicit expectations on future demand (see e.g. Guiso and Parigi, 1999), as SISF collects information both on the actual level of revenues and on its expected levels for the following year. The expected demand is strongly correlated with the ex-post realized demand so it can be credibly used as a measure of growth opportunities. In addition, apart from analyzing the real effects, we also analyze firm-level total bank credit.

As a proxy of monetary policy conditions, to fully exploit the time series, we use the size of the balance sheet of the ECB (after subtracting the autonomous factors which are

\footnotetext{
${ }^{16}$ For robustness, we use the change of log holdings as an alternative measure of banks' securities trading. In this case, we take care of initial purchases and final sales by adding one to the holdings, such that the logarithm is defined.
} 
beyond the direct control of the ECB) ${ }^{17}$ deflated by the nominal Italian GDP. This variable proxies for the series of unconventional monetary policies undertaken by the ECB to provide liquidity after the failure of Lehman Brothers in September 2008, such as the main refinancing operations (MRO) with full allotment (at fixed rate), the different LTROs (longterm refinancing operations) with different long-term maturity periods ( 3 months, 6 months, 1 year, 3 years...), and the purchases of securities by the ECB/Eurosystem such as Security Market Programme or Covered Bonds Purchase Programme. As detailed in the results section, we use alternative measures of monetary policy (based on shadow rates (Wu and Xia, 2017)), and also control for other macroeconomic variables, including time fixed effects, and via interactions of our key variables with the forecast of future economic activity, financial VIX, unemployment and inflation, among other variables. We also analyze a key measure of expansionary unconventional monetary policy, the two initial 3-year LTROs. The sample ends in December 31, 2013 because in 2014 the ECB also becomes the supervisor (with potential different incentives for bank risk-taking behavior) and introduces the negative rates thus making the policy rate an instrument of unconventional monetary policy. It is important to highlight that the European Central Bank, as compared to the Federal Reserve or the Bank of England for example, has had a key additional restriction in pursing expansive monetary policy during the crisis, coming from the presence of a clear, main mandate of pursuing price stability.

We also study conventional monetary policy in the pre-crisis period (January 1999 to August 2008); in this case our proxy for the monetary conditions is the Taylor (2008)-shock measure obtained by regressing EONIA (the overnight interest rate for the EURO area) on change in Italian GDP and Italian consumer price index (Adrian and Shin, 2011). ${ }^{18}$ Note that the monetary policy variables are normalized both in crisis and pre-crisis periods by the Italian nominal GDP (real GDP and prices), but results are similar if we normalize by Euro area nominal GDP. Both monetary policy measures (ECB balance sheet and short-term rates) moreover indicate softer monetary conditions if, given a level of economic activity and prices, the size of the central bank balance sheet is high or monetary policy rates are low; in addition to current economic and price conditions, we also control exhaustively (via time fixed effects and key interactions) by other key macro variables as the forecast of future GDP growth or financial risk and uncertainty. Note also that, as the ECB targets Euro area inflation, and Italy

\footnotetext{
${ }^{17}$ These include banknotes in circulation and government balances at central banks.

${ }^{18}$ Results are very similar if we directly use EONIA instead of the Taylor-shock residuals based on Adrian and Shin (2011) measure.
} 
is not perfectly synchronized with the Euro area, there is more exogenous variation of monetary policy in a monetary union with imperfect synchronization across different countries than otherwise. In Figure 1 we report the evolution of the total assets of the ECB and the EONIA rate during our sample period. Table 1 and Figure 1 show variability of the monetary policy variables. Note that EONIA is relatively flat during the crisis after the massive reduction following the failure of Lehman Brothers (in fact we show that results are very similar if we control in crisis times for EONIA in the key interactions). In the tables, to ease the comparison of the results with the crisis period, we multiply the Taylor shocks by -1, so that higher values of the monetary policy variable indicate softer monetary policy, as in the crisis period for the expansion of the ECB balance sheet.

\section{FIGURE 1 HERE}

We exploit bank capital heterogeneity as capital proxies the strength of both the bank balance sheets (hence the bank lending channel) and of agency conflicts (hence the risk-taking channel); note that the bank capital-to-total assets ratio is a sharp measure for both the intensity of the agency conflict between bank shareholders and their financiers (including depositors, debtholders and tax payers) and the strength of bank balance sheets (Holmstrom and Tirole, 1997; Bernanke, 2007; Freixas and Rochet, 2008). Therefore, bank capital is a key measure of the financial frictions faced by banks. As such, it has been identified as a key driver of banks' behavior during the crisis (Admati and Hellwig, 2013). ${ }^{19}$ For the reasons above, we exploit bank capital heterogeneity to identify the impact of softer monetary policy on the behavior of banks, both in terms of security holdings, and in terms of lending. For robustness we also use alternative proxies of bank capital such as capital in excess of the regulatory minimum (based on Tier 1) or bank net worth (capital ratio plus ROA). ${ }^{20}$ In the firm level regressions, where we analyze whether the preference for securities by banks with less capitalization translates into less credit and less real outcomes at the firm level

\footnotetext{
${ }^{19}$ Bank capital ratio is negatively related to the percentage of bad loans in crisis times, and positively correlated to ROA; both ROA and the percentage of bad loans are also measures related to the net-worth of banks. In addition, bank capital ratio is negatively related to bank size, therefore, apart for controlling for time-varying bank controls, in some regressions we also control in interactions of monetary policy and bank size.

${ }^{20}$ Demirguc-Kunt, Detragiache and Merrouche (2013) show that the capital ratio that is more associated to higher stock returns during financial crises is the leverage ratio (that we use), rather than the risk-adjusted capital ratio. E.g. Mariathasan and Merrouche (2014) show evidence on manipulation on risk weights for capital regulation in Basel II, and thus on Tier 1 ratio, whereas the leverage ratio is not based on risk weights.
} 
(investment, wage bill and sales), for each firm, we calculate a weighted average of the capital ratio of the banks they are exposed to (the weights are the shares of credit in the previous period, see e.g. Cingano et al. 2016, or Jiménez et al., forthcoming).

The capital ratio, the ratio of equity (shares subscribed, book value of equity plus retained earnings, divided by total assets) has an average value during the crisis of 7.7 per cent. There is a large variability among banks: the interquartile range goes from 6.5 to 8.7 per cent. Since trading and lending behavior may vary across banks, we control also for other bank variables, such as time-invariant heterogeneity via bank fixed effects, and time-varying bank controls: Size, the logarithm of the total assets; Liquidity, the sum of cash and sovereign bonds divided by total assets; Interbank, the ratio of total borrowing from other banks to total assets and Bad Loans/Total Assets.

To analyze reach-for-yield we use the yield as a measure of the risk of a security. The size of the yield is a superior measure of risk in comparison with rating since, as shown in Becker and Ivashina (2015), financial institutions may select securities with an ex-ante higher yield, within the same rating category, to increase risk by reaching for higher yield. Our main proxy for security risk, Yield, is calculated as the Yield-to-Redemption minus the overnight interest rate for the Euro area. The average yield in the crisis sample is 2.66 per cent with a very large standard deviation of 1.9. The average yield within the sub-sample of Italian government bonds is 20 basis points smaller than the average yield in the rest of the sample. Controlling for maturity, the differences in yields increase; for example, for short maturities, the difference between the two types of securities becomes much larger: within securities with residual maturity below two years, the average yield for Italian government bonds is 120 basis points smaller than the rest of the securities. ${ }^{21}$ In some specifications, we also use additional measures of security heterogeneity, like the residual maturity and the haircut applied by the $\mathrm{ECB}$ in repo loans. During the crisis, the interquartile range for the residual maturity is between 1 and 4.5 years, and the interquartile range for ECB haircut is between 1.5 and 6.5 per cent.

As for lending regressions, we use ex-ante loan interest rates and default probabilities. The advantage of loan interest rates is the symmetry with the yield in the security regressions. However, in the lending to SMEs firms, banks can have market power, so loan rates do not represent only firm risk but also market power (Jiménez, Ongena, Peydró and Saurina, forthcoming), hence we also exploit default probabilities proxied by the ex-ante z-scores. In

\footnotetext{
${ }^{21}$ Note that only the very best non-sovereign long-term debt could be issued in crisis times.
} 
particular, we use as a proxy for firm risk a dummy that equals to one if the z-score is higher or equal to 7, the threshold which identifies "high risk" firms (Rodano, Serrrano Velarde and Tarantino, 2015); in the crisis sub-period, 33 per cent of the firms applying for credit are considered high risk. ${ }^{22}$ We also use as a proxy for firm risk Loan Yield, which we calculate as the highest interest rate (minus overnight rate) paid by the firm in the pre-existing credit relations in the period just before the posting of new loan applications. The use of this measure reduces largely the sample: in the credit register, interest rates are available for a large and representative sample of bank-firm relationships, but not for the whole population and we are also excluding all those firms who apply for a loan for the first time. In the crisis sub-period, the average loan yield is 7.5 per cent with a standard deviation of 3.6 per cent. We use ex-ante loan yield paid by the firm as a robustness check.

As we explain in detail in the results section, our empirical analysis also sheds light on the empirical relevance of key financial frictions and channels used in finance models. We do so by analyzing the whole sample of securities, and different sub-samples (e.g. government bonds that have regulatory capital weights equal to zero, or e.g. held to maturity versus the trading book and available for sale portfolios, which have different accounting and regulatory treatment), and also by exploiting, in addition, other security variables such as haircuts in repo loans. Our results discriminate between different financial frictions and channels, in particular on: (i) risk-shifting due to low capital (also called gambling for resurrection or assetsubstitution) as the skin in the game is low, banks may take high risks (Holmstrom and Tirole, 1997; Freixas and Rochet, 2008); (ii) credit crunches due to low bank capital, as less capitalized banks tend to be in general more liquidity constrained and hence these banks may buy (market liquid) securities which have low haircuts for repo loans to obtain (public) funding liquidity (Rochet and Vives, 2004); (iii) regulatory capital arbitrage to minimize bank capital requirements, as banks with low capital may prefer buying assets with lower regulatory capital weight to economize on their low capital (Allen and Gale, 2007); (iv) riskbearing capacity depending on bank accounting and regulation on the different portfolios, as banks with low capital may take different risk depending on whether securities are in the held to maturity category versus in the trading and available for sale categories (higher bank capital allows more risk-taking as in Adrian and Shin (2011).

\footnotetext{
${ }^{22}$ The z-score takes values between 1 (least likely to default) and 9 (most likely to default).
} 


\section{Results}

In this section we present the estimated specifications and discuss the results, first analyzing the security-level regressions, and then the granting of loan applications, including overall bank changes in securities over loans and firm-level credit and real outcomes.

\subsection{The Specifications}

Our main empirical specification is the following:

$$
\begin{aligned}
\text { Trading }_{s b t}= & \beta_{1} \text { SofterMP }_{t-1}+\beta_{2} \text { Capital Ratio }_{b t-1} * \text { SofterMP }_{t-1}+ \\
& +\beta_{3} \text { Capital Ratio }_{b t-1} * \text { SofterMP }_{t-1} * \text { Yield }_{s t-1}+\text { Control }_{s b t}+\alpha_{s t}+\alpha_{b}+\varepsilon_{s b t}
\end{aligned}
$$

We analyze Trading of security $s$ by bank $b$ in month $t$ depending on the lagged measure of monetary policy (expansion of the ECB balance sheet minus the autonomous factors deflated by the Italian GDP), lagged bank capital and lagged security yield. All these measures are defined and explained in the previous section and in the Appendix. In the tables, we go from no controls whatsoever to fully saturating the specifications with fixed effects and observable controls. We always include the lower level of interactions (e.g. monetary policy and yield), unless they are absorbed by fixed effects (e.g., security*time fixed effects, where time is every month of every year, i.e. year:month; for the sake of brevity we refer to it as month). We include macro controls ( $\triangle$ CPI and $\Delta$ Unemployment) and bank controls (Size, Liquidity Ratio, Interbank, Bad Loans/Total Assets). In intermediate regressions we replace the macroeconomic, bank and security variables by different sets of fixed effects. The most demanding specification for the double and triple interactions includes security*time fixed effects $\left(\alpha_{\mathrm{st}}\right)$ and bank fixed effects $\left(\alpha_{\mathrm{b}}\right)$. We double cluster standard errors at the bank and security-time level. We also perform many different permutations of clustering as robustness checks (see below). In the last section, we also use a very similar framework to study how monetary policy conditions, bank, and firm characteristics affect the propensity of banks to grant new loan applications. Finally, we analyze the real effects associated.

\subsection{Unconventional Monetary Policy in Crisis times: the Security Portfolio}

The first three columns of Table 2 show that, when monetary policy is softer (ECB provides higher liquidity overall), banks react by increasing their holdings of securities (positive net buy of securities). In column 1 we do not control for any macro, bank or security 
characteristic, whereas in column 2 we control for the changes in Italian unemployment and inflation and bank observable characteristics, and in column 3 we additionally control for security fixed effects. Note that despite all these macro, bank and security controls, the positive estimated coefficients of ECB's monetary policy (Softer MP) on Italian banks' net buys of securities (column 1, 2 and 3) are not statistically different.

TABLE 2 HERE

We are interested in the reaction of banks with different capital to monetary policy. For this reason, in columns 4 to 8, we add the double interactions of Softer MP and Capital Ratio. We find that, when monetary policy is softer, banks with less capital buy more securities (the estimated double interaction Capital Ratio*Softer MP is negative). In column 4 we include time fixed effects to control fully for macro factors; in column 5, 6 and 7 we include again time fixed effects but restricting the sample to all securities different from either Italian nonfinancial corporate bonds (column 5) or Italian government bonds (column 6), and to only securities issued outside Italy (column 7); in column 8 we include rating *maturity*time fixed effects (where time is year:month). In all the specifications, the double interaction of bank capital and monetary policy has a very similar coefficient (not different statistically), although it is statistically insignificant at standard levels of confidence in column 7 , but note that the number of observations is reduced by approximately $90 \%$ (the estimated coefficients of column 4 and 7 are respectively -0.63 and -0.59 ). Therefore, banks with less capital expand more into securities when ECB provides high liquidity, and estimated effects are similar across all securities, government bonds and non-government bonds, and only foreign issued securities; results are also not driven by securities issued by Italian non-financial firms (note that these securities are a tiny percentage from a quantitative point of view, and do not cover SME firms). ${ }^{23}$

We are also interested in the impact of monetary policy on reach-for-yield by banks with different capital. For this, in column 9 we include the triple interaction Capital Ratio* Softer MP* Yield. In column 10 we introduce rating*maturity*time fixed effects (to control for the determinants of regulatory capital), in column 11 we include security*time fixed effects (to control fully for all unobserved and observed securities characteristics, including

\footnotetext{
${ }^{23}$ The interaction Softer MP *Yield is never statistically significant and the interaction Capital Ratio*Yield is not significant in most of the specifications.
} 
liquidity and risk aspects) and in column 12 we include both security*time and bank fixed effects. The triple interaction Capital Ratio*Softer MP*Yield is always positive and statistically significant (the double interaction Capital Ratio*Softer MP is always negative and significant, and the level effect of Softer MP is positive and significant). The results imply that, when monetary policy is softer (ECB provides higher liquidity), banks with less capital buy more securities, but with lower yield in comparison to more capitalized banks. All the estimated coefficients of the triple interactions across different specifications are very similar and not different statistically.

The results are also economically significant. One standard deviation increase in unconventional monetary policy is associated with an increase of 1.59 per cent in the net buys of securities (based on the coefficient of column 3 of Table 2), which corresponds to a semielasticity of 31 per cent. ${ }^{24}$ For the double interaction Capital Ratio* Softer MP, an increase in one standard deviation in unconventional monetary policy leads banks with low capital (25 percentile) to buy 0.42 per cent more securities than banks with high capital (75 percentile), which corresponds to 27 per cent of the average increase due to softer monetary policy. Finally, for the triple interaction Capital Ratio* Softer MP*Yield, when there is an increase in one standard deviation in unconventional monetary policy, banks with low capital (25 percentile) buy 0.48 per cent more securities with lower yield (one standard deviation) than banks with high capital (75 percentile), which corresponds to a 30 per cent of the average increase due to the softer monetary policy. Note that we calculate the economic significance of the double and triple interactions based on the coefficients obtained in the most demanding specification (column 12 of Table 2).

\subsection{Robustness checks}

Table 3 reports several robustness checks on the main coefficients of interest, the double interaction (Capital ratio*Softer MP) and the triple interaction (Capital ratio*Softer MP*Yield).

TABLE 3 HERE

\footnotetext{
${ }^{24}$ The differential impact of a one standard deviation change in the unconventional monetary policy variable on securities holdings over lending at the mean, in percent.
} 
First, we want to make sure that that our variables of Capital Ratio and Softer MP are really capturing what we want to measure and are not proxying for something else. For this reason, we first include a double (and triple) interaction between Softer MP and bank Size (and Yield). Note that bank size is the only bank variable correlated with capital in normal and crisis times. Second, in addition to the interactions with bank Size, we include also the double (and triple) interaction between Softer MP and bank Liquidity (and Yield), as bank liquidity is a key variable for the bank lending channel (Kashyap and Stein, 2000; Jimenez et al, 2012). Next, we include double (and triple) interactions between bank Capital Ratio and changes in VIX, Italian unemployment and forecasted future GDP in Italy (note that these variables may also influence ECB policy and risk-taking). ${ }^{25}$ Finally, we also add the double (and triple) interactions between bank Capital Ratio and EONIA (as the latter variable also has variation during the crisis, but substantially lower than the size of the ECB balance sheet). Note that when we control for the double and triple interactions with bank size and liquidity and with other macroeconomic variables, the results of our two coefficients of interest remain strongly statistically and economically significant. ${ }^{26}$

Second, we use different definitions for the two main variables: Capital Ratio and Softer $M P$. As for bank capital, we replace the capital to asset ratio with either the capital in excess of regulatory minimum, or a proxy of bank net worth (capital ratio plus ROA). As for the proxy for unconventional monetary policy, we modify the ratio of total assets of the ECB (net of the autonomous factors which are not under the control of the ECB) to the Italian nominal GDP in three ways: a) we include back the autonomous factors, b) we normalize the total assets of ECB by the Euro area GDP, c) we calculate the change in the total assets ECB relative to the overall average in the crisis, divided by the nominal Italian GDP. In all these specifications, the two coefficients of interest remain highly statistically significant and also the associated economic effects are very similar. Moreover, the coefficients of interest are significant also if we use a completely different proxy for unconventional monetary policy

\footnotetext{
${ }^{25}$ Regarding the VIX and the other macro controls, note that we control for unobserved overall time-varying shocks via time (or security*time) fixed effects, where time is year:month, hence with the interactions of VIX and the other macro controls we also control for differential effects of macro-financial shocks across different banks and different securities.

${ }^{26}$ Interestingly, the double Liquidity*Softer MP (unreported) is negative and statistically significant implying that banks with less liquidity buy more securities when monetary policy conditions are softer. Note also that regarding bank controls, the only two which are (robustly) statistically significant are bank size and liquidity. Moreover, the two coefficients of interest remain strongly significant also when we include the double (and triple) interaction between Softer MP and Bad Loans/Total Assets (and Yield) (unreported).
} 
which is not based on the total assets of the ECB but on the shadow rates $(\mathrm{Wu}$ and Xia, $2017) .^{27}$

Third, we assess the robustness of our findings to changing the sample of banks. We exclude from the analysis the largest three banks in our sample in terms of total assets, to confirm that our results are not just driven by a handful of large banks. These are the biggest banks in the country with the largest international presence, they have a large portfolio of securities, and rely more on derivatives. Results are still strong. In addition, we report Weighted Least Squares estimates where the weight is the level of the holdings of each security at the beginning of the month by each bank to give more weight to the largest holdings. WLS estimates of the coefficients are somewhat larger than the coefficients of the OLS regressions.

Fourth, a further concern could be that the results may be driven by diversification motives, therefore we control for the correlation of securities traded with the existing portfolio. In particular, we control for the existing portfolio of each bank at the beginning of each month, by including the shares of the bank portfolios invested in different type of securities according to the issuer: Italian government, foreign governments, Italian banks, foreign banks, Italian non-financial corporations, foreign non-financial corporations. Results do not change.

Fifth, we include additional fixed effects to control for further unobservables. We include bank*time fixed effects or security*bank fixed effects to control for unobserved timevarying bank heterogeneity, such as for example overall bank expansion, or time-invariant specific security and particular bank matching heterogeneity, proxying for example for different specialization of banks in some particular securities. The inclusion of these additional set of fixed effects do not change the coefficients of the baseline regression. ${ }^{28}$

Sixth, we try a different way of clustering the standard errors. Instead of double clustering at bank and security-time, we triple cluster at bank, security and time. Results do not change, since the size of the standard errors in the two specifications are very similar. Moreover, we also change the definition of the dependent variable used in the analysis. Instead of the Davis-Haltiwanger definition, we use the difference between the logarithm of

\footnotetext{
${ }^{27}$ Shadow rates data for Europe are downloaded from https://sites.google.com/site/jingcynthiawu/home/wu-xiashadow-rates.

${ }^{28}$ When we include bank*time fixed effects we cannot identify the coefficient of the double interaction Capital ratio*Softer MP.
} 
$(1+$ holdings of security $s$, by bank $b$ at time $t)$ and the logarithm of $(1+$ holdings of security $s$, by bank $b$ at time $t-1$ ). Results remain strongly significant.

Finally, instead of looking at the time series and analyzing the variations of the total assets of ECB as a proxy for the several unconventional monetary policy measures taken by the ECB, in the last row of Table 3 we analyze only one large shock: the first 3-Year LTROs, which represents the largest jump in the total assets of the ECB. With this measure, announced in December 2011, the ECB provided more than one trillion of (euro) lending with a three-year maturity to European banks. The funds were distributed in two allotment dates: December 21, 2011 and February 29, 2012. We analyze the net buys of securities in the month of the first allotment of the LTRO and the following three months, which also captures the second allotment date of the LTRO (i.e., December 2011- March 2012). Symmetrically to the main specification, we are interested in the coefficient of Capital Ratio and the double interaction Capital Ratio*Yield to analyze which banks bought which type of securities. We find that the coefficient of Capital Ratio is negative and the double interaction Capital Ratio*Yield is positive; both coefficients are highly statistically significant. ${ }^{29}$ During the months of the LTRO, banks with less capital buy more securities overall, but with lower yield, as compared to more capitalized banks. The results from the largest increase in the total assets of the ECB confirm the results of the main specification across all the crisis period. ${ }^{30}$

\subsection{Understanding the Drivers}

At least four potential channels could drive the results on the reach-for-yield (triple interaction) in securities: risk-shifting (gambling for resurrection or asset substitution), regulatory capital arbitrage, access to (public) liquidity, and risk-bearing capacity. The riskshifting hypothesis implies stronger risk-taking by less capitalized banks, as these banks have stronger incentive to take higher risk given their lower skin in the game. This testable prediction on the behavior of less-capitalized banks relative to more-capitalized ones is what

\footnotetext{
${ }^{29}$ Symmetrically to the main sample, in this new regression we control for other bank observable characteristics recorded at time $\mathrm{t}-1$ and include security*time fixed effects (here the standard errors are double clustered at bank and security level, as there is no time dimension).

${ }^{30}$ If we use, as a measure of softer monetary policy, the announcement of Mario Draghi "to do whatever it takes" on July, 2012, looking at the securities trading in the few months around the announcement, we do not find significant results. We believe this is consistent with our approach which is based on studying a differential reaction of securities trading across banks depending on their ex-ante capital. We expect this kind of differential effects when there are actual interventions from the ECB, as banks may then use the extra funds to purchase securities; while the "whatever it takes" announcement moved yields, it did not actually implied any actual activity from the ECB.
} 
we analyze in the paper. Our paper is silent on whether, in absolute terms, less capitalized banks do take, or not, excessive risks (these banks could e.g. buy only triple A securities). The robust evidence of a positive sign of the triple interaction Capital Ratio*Softer MP*Yield is inconsistent with the risk-shifting /gambling for resurrection hypothesis (banks with more capital buy the riskier securities). In this section, we bring additional evidence to shed light on the remaining three channels that could drive the results.

In Table 4 we analyze the possibility that the behavior of banks may be driven by regulatory arbitrage (buying of some securities to minimize capital requirements) and access to public liquidity (buying of some securities with lower haircuts to borrow at better conditions in repo operations). Table 4 shows estimates of the same regressions as in the baseline model, but restricting the sample to the holdings of Italian government bonds, which all have zero risk weights for regulatory capital. We look at yield but, here, we also look at maturity and haircuts applied by the ECB on collateral pledged to borrow money, as measures of security heterogeneity for liquidity purposes. Note that banks with less capital should have higher incentives to economize on capital, and hence they could buy securities with lower yield not because they are less risky, with lower yield, but because they could be associated to lower regulatory capital weights. In addition, banks with less capital may be more liquidity constrained, hence they may buy securities with lower yield (and risk) to repo them to obtain liquidity at better lending conditions as these securities may have lower haircut (we also analyze maturity as securities with short-term maturity have lower haircuts and are in general more liquid).

TABLE 4 HERE

Our findings indicate that - also within Italian government bonds - banks with smaller capitalization buy securities with lower yield when monetary policy is softer. Since all Italian government bonds have the same risk weights - zero -, this evidence suggests that regulatory arbitrage is not among the main drivers of banks trading. Note also that in Table 2 when we analyze all securities, we find that within the securities with identical rating and maturity in the same month (which are the main determinants of regulatory capital weights), we also find that banks with less capital buy securities with lower yield. Therefore, looking at all securities or at securities with zero regulatory capital weights, results do not support the regulatory 
capital arbitrage hypothesis. ${ }^{31}$ All these results are moreover very similar (not reported) when we use capital in excess of regulatory minimum instead of the capital ratio.

In Table 4 we also look directly at Maturity and Haircut as measures of security heterogeneity. We obtain from the Eurosystem the eligible marketable assets that can be used as collateral, and for each security, the applied haircut at each point in time. ${ }^{32}$ Consistently with the results on yield, the triple interactions of Capital Ratio*Softer MP*Long Maturity and Capital Ratio*Softer MP*Haircut are positive and statistically significant. Within Italian government bonds, which are the securities that Italian banks tend to use as collateral with the ECB, banks with less capital buy securities with short maturity or with low haircut. ${ }^{33}$ Note that results are robust to including bank*security fixed effects, in addition to security*time fixed effects. Note that the inclusion of security*bank fixed effects control for a preference of a bank for a particular security (e.g. a particular maturity horizon).

Finally, in Table 5 we explore the relevance of the risk-bearing capacity hypothesis. To this aim, we exploit information on the regulatory portfolio each security is held in, and we split the sample into securities placed in the held to maturity portfolio and securities placed in the other portfolios. If a security is in the held to maturity portfolio, unrealized changes in fair value are not reported on either the income statement or the balance sheet. ${ }^{34}$ On the contrary, in the other portfolios, the unrealized changes in fair value are recognized in the income statement (trading portfolio) or in the balance sheet in the comprehensive income (available for sale portfolio). If risk-bearing capacity drives less capitalized banks to buy securities with lower yield (following for instance Adrian and Shin (2011)), we should find the results of the triple interaction to be particularly strong in the portfolios, where securities are marked to market. This is exactly what we find in Table 5. The coefficient of the triple interaction in the held to maturity subsample is not significant (and has even the opposite sign in three out of

\footnotetext{
${ }^{31}$ Recall that less capitalized banks prefer securities over credit when there is overall higher ECB liquidity, which, prima facie, without our granular data, could have been suggestive of regulatory capital arbitrage. Given the overall results in Table 4, the liquidity hypothesis is more consistent with the results.

${ }^{32} \mathrm{We}$ do not find that a dummy variable on pledgeability is statistically significant (unreported), probably as most of the securities in our sample can be pledged at the ECB.

${ }^{33}$ Note that banks with less capital do not need to actually access the ECB, but, if in the future they need to access the ECB for additional funding (or potentially also in general markets), they can do it more cheaply or at higher volumes. Note also that the coefficients of the double interactions have similar magnitude than in the sample for all securities, except for the interactions with haircuts, where they become smaller only because the less capitalized banks buy more securities at the very low haircut level, not at the average level. Note that, within Italian public debt, the securities with shorter maturity also have lower haircuts in private repo markets (we have access to the ECB individual security haircut level, but not the private repo market ones at the security level).

${ }^{34}$ Unless there is objective evidence of impairment, for instance after a breach of contract, such as default or delinquency in interest or principal.
} 
the four specifications), whereas - in the other portfolios (available for sale and trading book) - the estimated triple interaction has a positive coefficient, which is statistically and economically significant. ${ }^{35}$ Also here, results are very similar (unreported) if we use capital in excess of regulatory minimum instead of the capital ratio.

TABLE 5 HERE

Our findings suggest that banks with more (not less) capital reach for higher yield; the effects are only present in the available for sale and trading books, but not in the held to maturity. ${ }^{36}$ Overall our findings are consistent with risk bearing capacity of banks, which is higher for banks with more capital in crisis times, and also with access to liquidity in crisis times, and not with regulatory capital arbitrage.

\subsection{Conventional Monetary Policy in Normal Times: the Security Portfolio}

Next, we concentrate on the pre-crisis period, from January 1999 to August 2008. The monetary policy in this period is proxied by Taylor-shocks (residuals), as explained in Section 2 . We multiply the Taylor shocks by -1 , so that higher values of the monetary policy variable imply softer monetary policy, as in the crisis period for the expansion of the ECB balance sheet. We run the same regressions as those shown in Table 2, but on a different sample period (pre-crisis) and with a different proxy for monetary policy (monetary policy rates). ${ }^{37}$ Results are shown in Table 6.

TABLE 6 HERE

\footnotetext{
35 The coefficients of the double interactions are statistically significant and have similar magnitude than in the main sample, except for the last column (with all the fixed effects in) in the held to maturity portfolio, where the double interaction is not only insignificant, but with an opposite sign.

${ }^{36}$ This also suggests that results are not driven by regulators and supervisors preventing less capitalized banks from taking on higher risk as compared to banks with high capital, as effects are different in the held to maturity than in the other portfolios. Note that our results are not based on banks at the very left tail of the distribution of bank capital which could be affected by a stricter oversight by the supervisor, but are average results.

${ }^{37}$ We use the residuals after regressing monetary policy rates on GDP and price changes; note that our crisis variable is also related to real GDP changes and price changes, as it is normalized to nominal GDP.
} 
Differently from the crisis period, we do not find that banks with less capital buy relatively more securities, as monetary policy becomes softer. The double interaction Capital Ratio*Softer MP is not statistically significant in any specification. Banks on average react to softer monetary policy by increasing their holdings of securities, but the effect is not heterogeneous across banks with different levels of capital. Therefore, when financial frictions are not strong (normal times), bank capital is not an important driver of the expansion of securities as monetary policy becomes softer. Finally, the coefficient of the triple interaction Capital Ratio* Softer MP* Yield is positive and significant at $10 \%$ in two specifications out of four. This suggests that low capital banks do not reach-for-yield in securities either during the crisis or during normal times.

\subsection{The Loan Portfolio}

We also study the impact of monetary policy on the granting of loan applications, especially for differently capitalized banks, including reach-for-yield in lending. Symmetrically with the specification on the security portfolio, we estimate equation (1) where the dependent variable is now Granting a Loan Application $_{i, b, t}$ which equals 1 if a loan application is granted to firm $i$ by bank $b$ over the quarter starting in month $t$, when the application was posted, and the measure of risk is the variable High Risk or Loan Yield (see Section 2 and Appendix for the exact definition of variables). Table 7 shows results. ${ }^{38}$

As in the securities regressions, the key variables of interest are the double interaction between bank capital and the proxy for monetary policy and the triple interaction between bank capital, the proxy for monetary policy and ex-ante firm risk. In column 1 we do not include any time dimension in the fixed effects (we have firm but not firm*time fixed effects), so that we can estimate the coefficient of monetary policy. We find that the coefficient is not statistically significant here, while it was significant in the security regressions, suggesting that the positive effects of softer monetary policy in the crisis is stronger in securities than in loans. Importantly, in crisis times, the double interaction Capital Ratio*Softer MP is positive and statistically significant, which suggests that banks with less capital grant fewer loan applications to the same firm in the same quarter as compared to banks with more capital (which is opposite of what we find in the securities trading regressions). Moreover, the

\footnotetext{
${ }^{38}$ As in the securities trading regressions, for the crisis sample (column 1 to 4 ) the variable Softer MP is the Total Assets of the ECB minus autonomous factors divided by the Italian nominal GDP; for the normal times sample (column 5 to 8), it is the Taylor shocks, based on EONIA (i.e. cleaned by Italian GDP and prices) and multiplied by $(-1)$.
} 
coefficient of the triple interaction is never significant in the crisis period (differently from the securities trading regressions). ${ }^{39}$

Note that in column 3, as a robustness check, we exclude firms with very high or very low z-score to test whether results hold around the z-score values which sort firms into safer and riskier, as identified by the literature (Rodano, Serrano-Velarde, Tarantino 2015), ${ }^{40}$ and we find that this is the case, indeed. Regarding economic effects, following an increase in one standard deviation in the unconventional monetary policy variable, banks with low capital (25 percentile) have a 0.81 percentage points lower probability of granting a loan application than banks with high capital (75 percentile) to the same firm in the same period, which corresponds to a semi-elasticity of 3.11 per cent. ${ }^{41}$ We calculate the economic significance on the basis of the coefficient of the double interaction Capital Ratio*Softer MP obtained in the most demanding specification (column 3 of Table 7).

\section{TABLE 7 HERE}

Columns 5 to 8 of Table 7 show estimates from the pre-crisis period. The double and triple interactions are not significant. The double interaction has a negative coefficient (the impact of softer monetary policy on the granting of applications is larger for less capitalized banks), opposite to the results for the crisis, though not statistically significant at conventional levels. The triple interaction with the loan yield is significant in the last column (banks with less capital take on higher risk in loans in normal times when monetary policy is softer), but this result is not confirmed when we use the measure based on z-score.

In Table A3 in the Appendix, we report additional evidence at the aggregate bank level to confirm the result that less capitalized banks react to softer monetary policy during the crisis by purchasing more securities rather than lending. We report OLS and WLS (with bank size as weight) regressions using data at the bank level, using all security holdings and all

\footnotetext{
${ }^{39}$ In addition, in column 4 , we also use as a proxy for firm risk Loan Yield, but also in this specification, the triple interaction is not significant.

${ }^{40}$ We restrict the sample to firms with a z-score between 5 and 8 . We remind here that our dummy Risky is equal to 1 if the score is larger or equal to 7 (see Section 2 for details).

${ }^{41}$ For each application, the average probability of being granted is 26.17 per cent.
} 
loans by banks, where the dependent variable is the ratio between securities and loans. ${ }^{42}$ The coefficient of the double interaction Capital Ratio* Softer MP is negative and statistically significant, which confirms, also with aggregate data, that banks with less capital increase more overall securities than overall lending volume as compared to banks with more capital. ${ }^{43}$ An increase in one standard deviation in unconventional monetary policy leads banks with low capital ( 25 percentile) to increase their securities/loans ratio by 1.49 per cent more than banks with high capital (75 percentile), which corresponds to a semi-elasticity of 7.25 per cent.

Finally, in Table 8 we analyze whether the preference for securities by banks with less capital translates into less credit and worse real outcomes (a reduction in investment, wage bill and sales) at the firm level. For each firm, we calculate a weighted average of the capital ratio of the banks they are exposed to (the weights are the shares of credit in the previous period, see e.g. Cingano et al. 2016, or Jiménez et al., forthcoming). The dependent variables are the change in the log of credit, several definitions of firm investment, ${ }^{44}$ the change in the $\log$ of firm overall wage bill and the change in the log of firm sales. We are interested in the coefficient of the lagged double interaction Weighted Capital Ratio*Softer MP. We control for several lagged firm level characteristics including, notably, a measure of expected demand obtained from the survey (to proxy for growth opportunities and overall firm demand) and for province*time and industry*time fixed effects. ${ }^{45}$

TABLE 8 HERE

We find that the coefficient of the interaction Weighted Capital Ratio*Softer MP is always positive and significant. After an increase in one standard deviation in unconventional monetary policy, firms exposed to banks with high capital (75 percentile), in comparison to

\footnotetext{
${ }^{42}$ This information is reported in the Supervisory Reports every six months and the loans here include both loans to firms and households. The average security/loans ratio in the crisis period is 20.55 per cent.

${ }^{43}$ The variable Softer MP enters the regression positively, which suggests that during the crisis, softer monetary policy has a stronger positive effect on securities than on loans, though it is not statistically significant at conventional levels.

${ }^{44}$ We present three definitions of investment rate: (a) the first measure is calculated as adjusted total assets ${ }_{\mathrm{t}^{-}}$ adjusted total assets $_{\mathrm{t}-1} /$ adjusted total assets $_{\mathrm{t}-1}$ (where adjusted total assets is equal to total assets - fair value revaluation); (b) the second measure is the same as the first one but without adjusting for the fair value revaluation; (c) the numerator in the third measure is a flow measure of investments from the income statement.

${ }^{45}$ It is worth noticing that the measure of expected demand is statistically significant at $1 \%$ and with the expected sign.
} 
firms exposed to banks with low capital (25 percentile), receive more credit, and increase investment, the wage bill and sales (respectively with the following semi-elasticities, 11 per cent, 10 per cent, 19 per cent and 11 per cent).

\section{Conclusions}

While a large empirical literature on the bank lending channel of monetary policy only analyzes credit, including compositional effects with respect to risk, there is no empirical evidence on the impact of monetary policy on banks' securities holdings, in addition to credit supply. As we argued in the paper, and as theory shows, this is important as (i) bank security trading can crowd out the supply of bank credit to non-financial firms, and (ii) it may be easier (faster) to reach for higher yield with securities rather than with loans.

We analyze the following questions. Does softer monetary policy in crisis times encourage banks to increase their holdings of securities? Do less capitalized banks prefer increasing securities holdings to increasing lending to firms? Is it because of lack of good borrowers in loan applications? Are there associated firm-level real effects? When central banks provide higher liquidity, which banks take on higher risk via reaching for higher yield? What are the main financial frictions and channels (drivers) in crisis times? What are the transmission differences in normal times?

We are in a unique position to answer the above questions since we have access to the matched security and credit application registers (including comprehensive security, loan, bank and firm characteristics) for banks in Italy, on a monthly basis, since the creation of the euro in 1999; this is especially important in a bank dominated economy where banks are the main providers of finance to non-financial corporations and are also key players in security markets.

In crisis times, we find that, with softer monetary policy, less capitalized banks prefer buying securities rather than increasing credit supply (and this is not due to lack of good loan applications). Results are identical if we exclude securities to Italian non-financial firms (which are tiny) or are very similar if we only analyze foreign issued securities (which are not directly supporting the Italian economy). In addition, the results suggest that this reduction in credit translates into real effects at the firm level: when monetary policy is softer, firms more exposed to banks with less (compared to more) capital get relatively less credit, with a subsequent reduction in firm investment, the wage bill and sales (which proxies for firm overall output). Results are overall, quantitatively, strong. Differently, in pre-crisis times, 
when financial frictions are limited, less capitalized banks do not expand securities holdings over credit supply.

Less capitalized banks may prefer securities over credit in crisis times to have more liquid assets, to economize on regulatory capital, and/or to risk-shift with securities. Therefore, to further understand the different drivers of our results, and to also test for the risk-taking (reach-for-yield) channel of monetary policy, we analyze further heterogeneous effects (across different securities and loans). We find that more - not less - capitalized banks reach-for-yield (with securities) in crisis times, when monetary policy is softer, which is against the risk-shifting hypothesis. Importantly, the result on reach-for-yield in securities is confined to securities which are in the available for sale and trading portfolios, and not in the held to maturity ones, which suggest that risk-bearing capacity is a key driver. Moreover, we find very similar results across securities with identical risk weights for regulatory capital, and hence pure regulatory capital arbitrage cannot explain the lower reach-for-yield by less capitalized banks. Finally, less capitalized banks buy more securities with lower haircut and maturity, which suggest that access to liquidity is another key driver of results.

Results are informative for theories about the interaction of finance and macro. Our results suggest that securities trading by banks may reduce the supply of credit to the real sector, with significant associated real effects (Shleifer and Vishny, 2010; Diamond and Rajan, 2011; Stein, 2013). Moreover, our results suggest that, as central banks provide high liquidity in crisis times, less capitalized banks do not take on higher risk as compared to banks with high capital, which is inconsistent with some corporate finance and banking theories based on moral hazard, in particular risk-shifting/gambling for resurrection (see e.g. Tirole, 2006; Freixas and Rochet, 2008; Admati and Hellwig, 2013).

Results are also informative on the current debate on public policy regarding banks, in particular on monetary and prudential policy. We show that there are limits to what expansive monetary policy can achieve in crisis since banks with low capital seem to use the additional liquidity to invest more on securities rather than to lend to the real economy (see e.g. Gambarcorta and Shin, 2016; Stiglitz, 2016). In addition, our results suggest that less bank capital does not imply higher reach-for-yield incentives when central banks provide high liquidity, which is important for the discussion on the interactions between monetary and macroprudential policies (Rajan, 2005; Allen and Rogoff, 2011; Stein, 2013). Moreover, since we show that less capitalized banks prefer securities with higher liquidity (low yield and haircut) over other securities and loans, policies facilitating the liquidity of loans may increase 
the potency of the bank lending channel, e.g. via a better market for securitization of SME loans (see e.g. the speech by Yves Mersch (2014) from the Executive Board of the ECB).

In addition, while there are proposals on limiting sovereign debt in banks on the basis of the recent academic literature on the sovereign-bank nexus (Brunnermeier, Garicano, Lane, Pagano, Reis, Santos, Thesmar, Van Nieuwerburgh and Vayanos, 2016) and the alleged gambling for resurrection with GIIPS sovereign debt by less capitalized banks in the periphery (see e.g. Acharya and Steffen, 2015), our results suggest that less capitalized banks take on lower risk during the crisis and that GIIPS non-sovereign securities and loans may be riskier, offering higher yields, and are quantitatively more important. Finally, our results are also interesting for the debate on policy restrictions to banks' security trading (not specific to sovereign bonds, as the Volker Rule in Dodd-Frank in the US, the Likaanen Report in EU and the Vickers' report in the UK) since, in the light of our evidence, banks do not seem to use security trading to risk-shift.

\section{References}

Abbassi, P., Iyer, R., Peydró, J.-L., \& Tous, F.R. (2016). Securities trading by banks and credit supply: micro-evidence from the crisis. Journal of Financial Economics, 121(3), 569-594.

Acharya, V. V., \& Steffen, S. (2015). The "greatest" carry trade ever? Understanding eurozone bank risks. Journal of Financial Economics, 115(2), 215-236.

Admati, A., \& Hellwig, M. (2014). The Bankers' New Clothes: What's Wrong with Banking and What to Do About it. Princeton, NJ: Princeton University Press.

Adrian, T., \& Shin, H. S. (2011). Financial intermediaries and monetary economics in Handbook of Monetary Economics, ed. by Friedman B. M., and Woodford M. Elsevier. Amsterdam: Elsevier.

Allen, F. \& Carletti, E. (2008). Mark-to-market accounting and liquidity pricing. Journal of accounting and economics, 45, 358-378.

Allen, F., Carletti, E., \& Gale, D. (2014). Money, financial stability and efficiency. Journal of Economic Theory, 149, 100-127.

Allen, F., Chui, M. K., \& Maddaloni, A. (2004). Financial systems in Europe, the USA, and Asia. Oxford Review of Economic Policy, 20(4), 490-508. 
Allen, F., \& Gale, D. (2007). Understanding Financial Crises. Oxford: Oxford University Press.

Allen, F., \& Rogoff, K. (2011). Asset prices, financial stability and monetary policy. In The Riksbank's Inquiry into the Risks in the Swedish Housing Market, ed. by P. Jansson, and M. Persson. Stockholm: Sveriges Riksbank, 189-218.

Altavilla, C., Pagano, M., \& Simonelli, S. (2016) Bank exposures and sovereign stress transmission. Working paper.

Bagehot, W., (1973). Lombard Street: A Description of the Money Market. New York, NY: E.P. Dutton and Company.

Becker, B., \& Ivashina, V. (2015). Reaching for yield in the bond market. Journal of Finance, 70(5),1863-1902.

Bernanke, B. S., \& Blinder, A. S. (1988). Credit, money, and aggregate demand. American Economic Review, 78(2), 435-39.

Bernanke, B. S., \& Blinder, A. S. (1992). The federal funds rate and the channels of monetary transmission. American Economic Review, 82(4), 901-921.

Bernanke, B. S., \& Gertler, M. (1995). Inside the black box: the credit channel of monetary policy transmission. Journal of Economic Perspectives, 9(4), 27-48.

Bernanke, B. S. \& Lown, C. S. (1991). The credit crunch. Brookings papers on economic activity, 1991(2), 205-247.

Bernanke, B. (2007). Speech at the Credit Channel of Monetary Policy in the Twentyfirst Century Conference. Federal Reserve Bank of Atlanta, Georgia.

Bocola, L. (2016). The pass-through of sovereign risk. Journal of Political Economy, 124(4), 879-926.

Bofondi, M., Carpinelli, L., \& Sette, E. (2017). Credit supply during a sovereign debt crisis. Journal of the European Economic Association, forthcoming.

Bolton, P. \& Freixas, X. (2006). Corporate finance and the monetary transmission mechanism. Review of Financial Studies 19 (3), 829-870.

Borio, C., \& Zhu, H. (2008). Capital regulation, risk-taking and monetary policy: a missing link in the transmission mechanism. Working Paper. 
Brunnermeier, M. K., Garicano, L., Lane, P. R., Pagano, M., Reis, R., Santos, T., Thesmar, D., Van Nieuwerburgh, S., \& Vayanos, D. (2016). The sovereign-bank diabolic loop and ESBies. American Economic Review. Papers and Proceedings, 106(5), 508-512.

Carpinelli, L. \& Crosignani, M. (2017). The effect of central bank liquidity injections on bank credit supply. Working paper.

Chakraborty, I., Goldstein, I., \& MacKinlay, A. (2016). Monetary stimulus and bank lending. Wharton Mimeo.

Cingano, F., Manaresi, F., \& Sette E. (2016). Does credit crunch investments down? New evidence on the real effects of the bank-lending channel. Review of Financial Studies 29 (10), 2737-2773.

Coimbra, N., \& Rey, H. (2017). Financial cycles with heterogeneous intermediaries. NBER Working Paper No. 23245.

Crosignani, M., Faria-e-Castro, M., \& Fonseca, L. (2016). The (unintended?) consequences of the largest liquidity injection ever. Working paper.

Davis, S., \& Haltiwanger, J. (1992). Gross job creation, gross job destruction and employment reallocation. Quarterly Journal of Economics, 107(3), 819-63.

Dell'Ariccia, G., Laeven, L. \& Marquez, R. (2014). Monetary policy, leverage, and bank risk-taking. Journal of Economic Theory, 149, 65-99.

Demirguc-Kunt, A., Detragiache, E. \& Merrouche, O. (2013). Bank capital: lessons from the crisis. Journal of Money Credit and Banking, 45(6), 1147-1164.

Diamond, D. W., \& Rajan, R. G. (2006). Money in a theory of banking. American Economic Review, 96(1), 30-53.

Diamond, D. W., \& Rajan, R. G. (2011). Fear of fire sales, illiquidity seeking, and credit freezes. Quarterly Journal of Economics, 126(2), 557-591.

Diamond, D. W., \& Rajan, R. G. (2012). Illiquid banks, financial stability, and interest rate policy. Journal of Political Economy, 120(3), 552-591.

Di Maggio, M., Kermani, A. \& Palmer, C. (2016). How quantitative easing works: evidence on the refinancing channel. Working paper, Columbia Business School Research Paper 16-1. 
Di Patti, E. B., \& Sette, E. (2016). Did the securitization market freeze affect bank lending during the financial crisis? Evidence from a credit register. Journal of Financial Intermediation, 25, 54-76.

Draghi, M. (2014). The path to recovery and the ECB's role. Speech by Mario Draghi President of the ECB. Frankfurt am Main, February 27.

Draghi, M. (2015). Hearing at the European Parliament's Economic and Monetary Affairs Committee. Speech by Mario Draghi, President of the ECB. Brussels, March 23.

Drechsler, I., Drechsel, T., Marques-Ibanez, D., \& Schnabl, P. (2016). Who borrows from the lender of last resort? The Journal of Finance, 71(5), 1933-1974.

Freixas, X., Laeven, L., \& Peydró, J.-L. (2015). Systemic Risk, Crises, and Macroprudential regulation. Cambridge, MA: MIT Press.

Freixas, X., Martin, A., \& Skeie, D. (2011). Bank liquidity, interbank markets, and monetary policy. Review of Financial Studies, 24(8), 2656-2692.

Freixas, X., \& Rochet J. C. (2008). The Microeconomics of Banking. Cambridge: MA: MIT Press.

Gambacorta, L., \& Shin, H. S. (2016). Why bank capital matters for monetary policy. Journal of Financial Intermediation, forthcoming.

Gennaioli, N., Martín, A. \& Rossi, S. (2014). Sovereign default, domestic banks and financial institutions. Journal of Finance, 69 (2), 819-866.

Gertler, M., \& Gilchrist, S. (1994). Monetary policy, business cycles, and the behavior of small manufacturing firms. Quarterly Journal of Economics, 109(2), 309-340.

Gertler, M., \& Kiyotaki, N. (2010). Financial intermediation and credit policy in business cycle analysis economics in Handbook of Monetary Economics, ed. by Friedman B. M., and Woodford M. Elsevier. Amsterdam: Elsevier.

Guiso, L., \& Parigi, G. (1999). Investment and demand uncertainty. Quarterly Journal of Economics, 114(1), 185-227.

Holmstrom, B., \& Tirole, J. (1997). Financial intermediation, loanable funds, and the real sector. Quarterly Journal of economics, 112(3), 663-691.

Horváth, B. L., Huizinga, H., \& Ioannidou, V. (2015). Determinants and valuation effects of the home bias in European banks' sovereign debt portfolios. Working paper. 
Ippolito, F., Peydró, J.-L., Polo, A., \& Sette, E. (2016). Double bank runs and liquidity risk management. Journal of Financial Economics, 122(1), 135-154.

Jiménez, G., Ongena, S., Peydró, J.-L. \& Saurina, J. (2012). Credit supply and monetary policy: identifying the bank balance-sheet channel with loan applications. American Economic Review, 102(5), 2301-2026.

Jiménez, G., Ongena, S., Peydró, J.-L., \& Saurina, J. (2014). Hazardous times for monetary policy: What do twenty-three million bank loans say about the effects of monetary policy on credit risk-taking? Econometrica, 82(2), 463-505.

Jiménez, G., Ongena, S., Peydró, J.-L., \& Saurina, J. (2017). Macroprudential policy, countercyclical bank capital buffers and credit supply: Evidence from the Spanish dynamic provisioning experiments. Journal of Political Economy, forthcoming.

Kashyap, A. K., \& Stein, J. C., (2000). What do a million observations on banks say about the transmission of monetary policy? American Economic Review, 90(3), 407-428.

Mariathasan, M. \& Merrouche, O. (2014). The manipulation of Basel risk-weights. Journal of Financial Intermediation, 23(3), 300-321.

Martinez-Miera, D. \& Repullo, R. (Forthcoming). Search for yield. Econometrica.

Mersch, Y. (2014). Banks, SMEs and securitisation. Speech by Yves Mersch, Member of the Executive Board of the ECB. London, 7 April.

Peek, J., \& Rosengren, E. S. (2000). Collateral damage: Effects of the Japanese bank crisis on real activity in the United States. American Economic Review, 90(1), 30-45.

Praet, P. (2016). Monetary policy and the euro area banking system. Speech by Peter Praet, Member of the Executive Board of the ECB. Madrid, October 4.

Rajan, R. G. (2005). Has finance made the world riskier? Speech presented at Jackson Hole, Federal Reserve Bank, Federal Reserve Bank, August.

Rochet, J.-C. \& X. Vives (2004). Coordination failures and the lender of last resort: was Bagehot right after all? Journal of the European Economic Association, 6(2), 1116-1147.

Rodano, G., Serrano-Velarde, N., \& Tarantino, E. (2015). Lending standards over the credit cycle. Working paper.

Rogoff, K. S. (2015). Debt supercycle, not secular stagnation. Vox http://www.voxeu.org/article/debt-supercycle-not-secular-stagnation 
Stein, J. (1998). An adverse-selection model of bank asset and liability management with implications for the transmission of monetary policy. RAND Journal of Economics, 29(3), 466-486.

Shleifer, A., \& Vishny, R. (2010). Unstable banking. Journal of Financial Economics, 97(3), 306-318.

Stein, J. C. (2012). Monetary policy as financial-stability regulation. Quarterly Journal of Economics, 127 (1): 57-95.

Stein, J. (2013). The fire-sales problem and securities financing transactions. Speech by Governor Jeremy C. Stein at the Federal Reserve Bank of New York. New York, October 4.

Stein, J. (2013). Overheating in credit Markets: Origins, measurement, and policy responses. Speech by Federal Reserve Board Governor Jeremy Stein. February 7, 2013.

Stiglitz, J. (2016). The theory of credit and macro-economic stability. NBER working paper 22837.

Summers, L. H. (2014). Reflections on the new 'Secular Stagnation' hypothesis. Vox http://voxeu.org/article/larry-summers-secular-stagnation

Taylor, J. B. (2008). The financial crisis and the policy responses: an empirical analysis of what went wrong. Working paper.

Tirole, J. (2006). The Theory of Corporate Finance. Princeton, NJ: Princeton University Press.

Wu, J. C., \& Xia, F. D. (2017). Time-varying lower bound of interest rates in Europe. Chicago Booth Research Paper No. 17-06. 
Figure 1. Conventional and Unconventional Monetary Policy

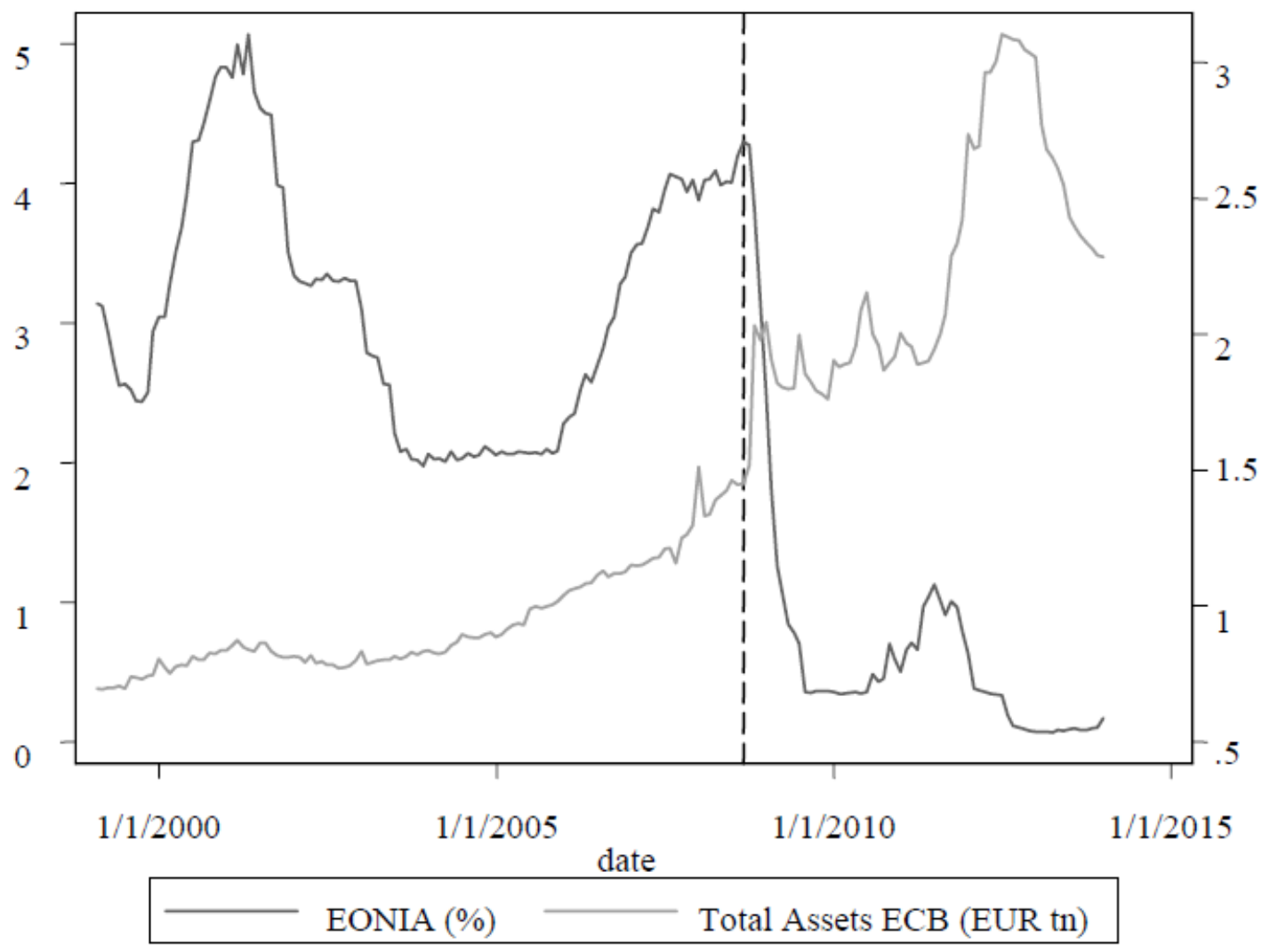

This figure reports the evolution of EONIA and the Total Assets of the ECB between January 1999 and December 2013. On the left axis is reported the EONIA in percentage. On the right axis is reported the Total Assets of the ECB in trillion euros. The dashed vertical line corresponds to the end of August 2008. 
Table 1: Descriptive Statistics

\begin{tabular}{|c|c|c|c|c|c|}
\hline Panel A: Crisis Times & Mean & St.Dev. & Median & $\mathrm{p} 25$ & p75 \\
\hline \multicolumn{6}{|l|}{ Security Holdings } \\
\hline Trading & 5.138 & 79.697 & -0.003 & -1.309 & 2.133 \\
\hline$\Delta$ Log (Holdings) & 22.536 & 285.673 & -0.003 & -1.309 & 2.133 \\
\hline \multicolumn{6}{|l|}{ Monetary Policy Proxy } \\
\hline Total Assets ECB/Italian GDP & 1.258 & 0.315 & 1.092 & 1.017 & 1.538 \\
\hline \multicolumn{6}{|l|}{ Bank Characteristics } \\
\hline Size & 10.255 & 1.984 & 10.223 & 8.454 & 11.824 \\
\hline Capital Ratio & 7.718 & 1.915 & 7.703 & 6.489 & 8.665 \\
\hline Excess Capital & 2.532 & 1.493 & 2.350 & 1.550 & 3.112 \\
\hline Net Worth & 7.972 & 1.984 & 7.999 & 6.850 & 8.972 \\
\hline Liquidity Ratio & 10.799 & 7.496 & 9.252 & 5.894 & 13.055 \\
\hline Interbank & 8.488 & 9.650 & 6.368 & 2.950 & 9.717 \\
\hline Bad Loans/ Total Assets & 3.393 & 1.955 & 3.446 & 1.801 & 4.610 \\
\hline Securities/Loans & 47.769 & 95.065 & 22.009 & 10.526 & 36.647 \\
\hline \multicolumn{6}{|l|}{ Security Characteristics } \\
\hline Yield & 2.659 & 1.873 & 2.304 & 1.324 & 3.698 \\
\hline Yield (Italian Gov.) & 2.528 & 1.730 & 2.319 & 1.002 & 3.940 \\
\hline Yield (Non Italian Gov.) & 2.727 & 1.939 & 2.296 & 1.453 & 3.574 \\
\hline Residual Maturity (months) & 46.533 & 63.067 & 25.433 & 11.133 & 53.267 \\
\hline Rating $=\mathrm{AAA}$ & 0.077 & 0.266 & 0 & 0 & 0 \\
\hline Rating $>=\mathrm{A}$ & 0.651 & 0.477 & 1 & 0 & 1 \\
\hline Haircut & 6.255 & 6.165 & 5.500 & 1.500 & 6.500 \\
\hline \multicolumn{6}{|l|}{ Macro controls } \\
\hline$\Delta \mathrm{CPI}$ & 0.157 & 0.219 & 0.200 & 0.000 & 0.300 \\
\hline$\Delta$ Unemployment & 0.090 & 0.212 & 0.000 & -0.100 & 0.300 \\
\hline \multicolumn{6}{|l|}{ Loans } \\
\hline $\begin{array}{l}\text { Granting at Least One Loan } \\
\text { Application }(\mathrm{x} 100)\end{array}$ & 39.884 & 48.966 & 0 & 0 & 100 \\
\hline \multicolumn{6}{|l|}{ Firms } \\
\hline$\Delta \log ($ Credit $)(x 100)$ & -6.980 & 37.300 & -3.380 & -18.800 & 8.410 \\
\hline Investment Rate (x100) & 7.164 & 49.180 & -1.145 & -7.757 & 9.639 \\
\hline$\Delta \log ($ Wage bill $)(\mathrm{x} 100)$ & -1.105 & 17.620 & 1.122 & -6.178 & 6.733 \\
\hline$\Delta \log ($ Sales $)(x 100)$ & -4.280 & 27.001 & -1.100 & -13.700 & 8.970 \\
\hline Loan Yield & 7.496 & 3.587 & 7.325 & 4.994 & 9.685 \\
\hline Firm High Risk & 0.329 & 0.470 & 0 & 0 & 1 \\
\hline Weighted Capital Ratio & 7.314 & 1.117 & 7.260 & 6.820 & 7.720 \\
\hline Firm ROA & -0.514 & 9.903 & 0.494 & -1.258 & 2.779 \\
\hline Firm Size & 10.070 & 1.458 & 9.879 & 9.036 & 11.000 \\
\hline Firm Expected Demand & 3.677 & 13.080 & 2.586 & -0.677 & 8.108 \\
\hline
\end{tabular}

The table shows descriptive statistics of the main variables employed in our analysis for the crisis period (from September 2008) 
Table 2: Unconventional Monetary policy, Bank Capital and Reach-for-Yield in the Security Portfolio in Crisis Times

\begin{tabular}{|c|c|c|c|c|c|c|c|c|c|c|c|c|}
\hline \multirow[t]{2}{*}{ Dependent Variable: } & \multicolumn{12}{|c|}{ Trading $_{\mathrm{s}, \mathrm{b}, \mathrm{t}}$} \\
\hline & (1) & (2) & (3) & (4) & (5) & (6) & (7) & (8) & (9) & (10) & (11) & (12) \\
\hline Softer MP & $\begin{array}{c}3.562 * * * \\
(0.692)\end{array}$ & $\begin{array}{c}4.337 * * * \\
(1.001)\end{array}$ & $\begin{array}{l}5.054 * * \\
(2.055)\end{array}$ & & & & & & $\begin{array}{c}4.459 * * * \\
(1.031)\end{array}$ & & & \\
\hline Capital Ratio* Softer MP & & & & $\begin{array}{c}-0.639 * * \\
(0.293)\end{array}$ & $\begin{array}{c}-0.673 * * \\
(0.323)\end{array}$ & $\begin{array}{c}-0.935 * * \\
(0.366)\end{array}$ & $\begin{array}{c}-0.591 \\
(1.537)\end{array}$ & $\begin{array}{l}-0.570 * \\
(0.339)\end{array}$ & $\begin{array}{c}-1.054 * * * \\
(0.324)\end{array}$ & $\begin{array}{c}-0.939 \text { ** } \\
(0.392)\end{array}$ & $\begin{array}{c}-0.868 * * * * \\
(0.299)\end{array}$ & $\begin{array}{l}-0.624 * \\
(0.345)\end{array}$ \\
\hline Capital Ratio* Softer MP*Yield & & & & & & & & & $\begin{array}{c}0.415^{* * * *} \\
(0.160)\end{array}$ & $\begin{array}{c}0.395^{* * *} \\
(0.158)\end{array}$ & $\begin{array}{c}0.389 * * \\
(0.149)\end{array}$ & $\begin{array}{c}0.377 * * \\
(0.149)\end{array}$ \\
\hline Capital Ratio*Yield & & & & $\begin{array}{l}0.108 * * \\
(0.0478)\end{array}$ & $\begin{array}{l}0.123 * * \\
(0.0513)\end{array}$ & $\begin{array}{c}0.113 \\
(0.0710)\end{array}$ & $\begin{array}{c}0.255 \\
(0.175)\end{array}$ & $\begin{array}{c}0.128^{*} \\
(0.0669)\end{array}$ & $\begin{array}{c}0.006 \\
(0.062)\end{array}$ & $\begin{array}{c}0.019 \\
(0.071)\end{array}$ & $\begin{array}{l}-0.008 \\
(0.066)\end{array}$ & $\begin{array}{c}0.012 \\
(0.064)\end{array}$ \\
\hline Softer MP *Yield & & & & $\begin{array}{l}-0.296 \\
(0.397) \\
\end{array}$ & $\begin{array}{l}-0.685^{*} \\
(0.412) \\
\end{array}$ & $\begin{array}{l}-0.126 \\
(0.439) \\
\end{array}$ & $\begin{array}{l}-0.899 \\
(1.127)\end{array}$ & $\begin{array}{c}-1.585^{* *} \\
(0.745) \\
\end{array}$ & $\begin{array}{c}0.169 \\
(0.364)\end{array}$ & $\begin{array}{c}-1.684 * * \\
(0.707) \\
\end{array}$ & & \\
\hline Macro Controls & No & Yes & Yes & - & - & - & - & - & Yes & - & - & - \\
\hline Bank Controls & No & Yes & Yes & Yes & Yes & Yes & Yes & Yes & Yes & Yes & Yes & Yes \\
\hline Time Fixed Effects & No & No & No & Yes & Yes & Yes & Yes & - & No & - & - & - \\
\hline Security Fixed Effects & No & No & Yes & No & No & No & No & No & No & No & - & - \\
\hline Bank Fixed Effects & No & No & No & No & No & No & No & No & No & No & No & Yes \\
\hline Rating*Maturity*Time Fixed Effects & No & No & No & No & No & No & No & Yes & No & Yes & - & - \\
\hline Security*Time Fixed Effects & No & No & No & No & No & No & No & No & No & No & Yes & Yes \\
\hline Observations & 225364 & 225364 & 225364 & 225364 & 216535 & 146114 & 21224 & 179501 & 225364 & 179501 & 225364 & 225364 \\
\hline
\end{tabular}

The table shows regressions of trading of security $s$ by bank $b$ at time $t$, as a function of a set of macroeconomic, security and bank variables at time $t$-1. Macro controls include changes in Italian unemployment and inflation. Bank controls include capital ratio, interbank, liquidity ratio, bad loans/total assets and size. In this table, the variable Softer MP is the Total Assets of the ECB minus autonomous factors divided by the Italian GDP. The sample period starts in September 2008. In column 5 we restrict the sample to securities which are different from Italian non-financial corporation bonds. In column 6 we restrict the sample to securities which are different from Italian government bonds. In column 7 we restrict the sample to securities issued outside Italy. See Appendix for exact definitions of variables and Section 2 for empirical strategy and data. We always include the lower level of interactions or standalone variables, unless they are absorbed by fixed effects. Fixed effects are either included ("Yes"), not included ("No") or spanned by another set of effects ("-"). Standard errors are double-clustered at bank and security-time level, and are reported in parentheses. *** $\mathrm{p}<0.01, * * \mathrm{p}<0.05, * \mathrm{p}<0.1$. 


\section{Table 3: Unconventional Monetary policy, Bank Capital and Reach-for-Yield in the Security Portfolio in Crisis Times - Sensitivity Analysis of Interactions}

\begin{tabular}{|c|c|c|c|}
\hline & $\begin{array}{l}\text { Capital Ratio* } \\
\text { Softer MP } \\
\end{array}$ & $\begin{array}{c}\text { Capital Ratio* } \\
\text { Softer MP *Yield }\end{array}$ & Observations \\
\hline \multirow[t]{2}{*}{ Baseline Result } & $-0.868^{* * *} *$ & $0.389^{* *}$ & 225364 \\
\hline & $(0.299)$ & $(0.149)$ & \\
\hline \multirow{2}{*}{$\begin{array}{l}\text { Controlling for double (and triple) interaction between Softer MP and bank } \\
\text { Size (and Yield) }\end{array}$} & $-0.920 * * *$ & $0.404 * * *$ & 225364 \\
\hline & $(0.288)$ & $(0.153)$ & \\
\hline \multirow{2}{*}{$\begin{array}{l}\text { Controlling for double (and triple) interaction between Softer MP and bank } \\
\text { Size and Liquidity (and Yield) }\end{array}$} & $-1.295 * * *$ & $0.454 * *$ & 225364 \\
\hline & $(0.410)$ & $(0.182)$ & \\
\hline \multirow{2}{*}{$\begin{array}{l}\text { Controlling for double (and triple) interaction between bank Capital Ratio } \\
\text { and changes in VIX, Italian unemployment and forecasted Italian GDP } \\
\text { (and Yield) }\end{array}$} & $-1.065 * * *$ & $0.291 * *$ & 225364 \\
\hline & $(0.310)$ & $(0.137)$ & \\
\hline \multirow{2}{*}{$\begin{array}{l}\text { Controlling for double (and triple) interaction between bank Capital Ratio } \\
\text { and EONIA (and Yield) }\end{array}$} & -1.117 **** & $0.532 * * *$ & 225364 \\
\hline & $(0.339)$ & $(0.188)$ & \\
\hline \multirow[t]{2}{*}{ Different proxy for Capital Ratio: capital in excess of regulatory minimum } & $-0.989 * *$ & $0.520 * *$ & 225364 \\
\hline & $(0.423)$ & $(0.224)$ & \\
\hline \multirow[t]{2}{*}{ Different proxy for Capital Ratio: net worth (capital ratio + roa) } & $-0.700 * *$ & $0.362 * *$ & 225364 \\
\hline & $(0.330)$ & $(0.159)$ & \\
\hline \multirow{2}{*}{$\begin{array}{l}\text { Different proxy for Softer MP: inclusion of net autonomous factors in total } \\
\text { assets ECB }\end{array}$} & $-0.808^{* *}$ & $0.351 * *$ & 225364 \\
\hline & $(0.331)$ & $(0.148)$ & \\
\hline \multirow{2}{*}{$\begin{array}{l}\text { Different proxy for Softer MP: normalization of total assets ECB by Euro } \\
\text { Area GDP }\end{array}$} & $-0.052 * * *$ & $0.023 * *$ & 225364 \\
\hline & $(0.012)$ & $(0.009)$ & \\
\hline \multirow{2}{*}{$\begin{array}{l}\text { Different proxy for Softer MP: change in the total assets ECB relative to } \\
\text { the overall time average in the crisis, divided by the nominal Italian GDP }\end{array}$} & $-0.899 * * *$ & $0.400 * * *$ & 225364 \\
\hline & $(0.297)$ & $(0.151)$ & \\
\hline \multirow{2}{*}{$\begin{array}{l}\text { Different proxy for Softer MP: dummy equal to } 1 \text { if shadow rates are } \\
\text { negative }\end{array}$} & $-0.527 * *$ & $0.225^{*}$ & 225421 \\
\hline & $(0.226)$ & $(0.116)$ & \\
\hline \multirow{2}{*}{$\begin{array}{l}\text { Different proxy for Softer MP: dummy equal to } 1 \text { if shadow rates are } \\
\text { below } 25^{\text {th }} \text { percentile }\end{array}$} & $-0.608 * *$ & $0.298 * * *$ & 225421 \\
\hline & $(0.264)$ & $(0.109)$ & \\
\hline \multirow[t]{2}{*}{ Exclusion of top three banks } & $-1.030 * * *$ & $0.419 * *$ & 171493 \\
\hline & $(0.271)$ & $(0.170)$ & \\
\hline \multirow[t]{2}{*}{ Weighted Least Squares regressions (weight: level of holdings) } & $-2.480 * * *$ & $0.921 * * *$ & 225364 \\
\hline & $(0.922)$ & $(0.244)$ & \\
\hline \multirow{2}{*}{$\begin{array}{l}\text { Controlling for the existing portfolio at the beginning of each month by } \\
\text { including the shares of the bank portfolios invested in different type of } \\
\text { securities according to the issuer }\end{array}$} & $-0.970 * * *$ & $0.369 * *$ & 225364 \\
\hline & $(0.308)$ & $(0.149)$ & \\
\hline \multirow[t]{2}{*}{ Inclusion of bank $*$ time fixed effects } & - & $0.273^{*}$ & 225357 \\
\hline & & $(0.164)$ & \\
\hline \multirow[t]{2}{*}{ Inclusion of security*bank fixed effects } & $-1.389 * *$ & $0.413^{*}$ & 223572 \\
\hline & $(0.553)$ & $(0.209)$ & \\
\hline \multirow[t]{2}{*}{ Triple clustering of standard errors at security, bank and time } & $-0.868 * * *$ & $0.389 * *$ & 225364 \\
\hline & $(0.263)$ & $(0.154)$ & \\
\hline \multirow{2}{*}{$\begin{array}{l}\text { Different definition of Trading (difference between the logarithm of } \\
\text { holdings at time } t \text { and the logarithm of holdings at time } t-1 \text { ) }\end{array}$} & $-2.922 * *$ & $1.745 * * *$ & 225364 \\
\hline & $(1.291)$ & $(0.607)$ & \\
\hline \multirow{3}{*}{ Using only the 4 months of the LTRO shock (December 11- March 12) } & Capital Ratio & $\begin{array}{l}\text { Capital Ratio } \\
\text { *Yield }\end{array}$ & \\
\hline & $-2.027 * * *$ & $0.481 * *$ & 17097 \\
\hline & $(0.714)$ & $(0.218)$ & \\
\hline
\end{tabular}

The table shows regressions of trading of security $s$ by bank $b$ at time $t$, as a function of a set of macroeconomic, security and bank variables at time $t$ - 1 . The sample period starts in September 2008. Rows correspond to perturbations of benchmark methodology. See Appendix for exact definitions of variables and Section 2 for empirical strategy and data. Security*time fixed effects are always included. Standard errors are doubleclustered at bank and security-time level, and are reported in parentheses. In the last row we include security fixed effects and standard errors are double-clustered at bank and security level. $* * * \mathrm{p}<0.01, * * \mathrm{p}<0.05, * \mathrm{p}<0.1$. 
Table 4: Regulatory Arbitrage or Access to Public Liquidity? The Portfolio of Italian Government Bonds

\begin{tabular}{|c|c|c|c|c|c|c|c|c|c|c|c|c|}
\hline \multirow[t]{2}{*}{ Dependent variable: } & \multicolumn{12}{|c|}{ Trading $_{s, b, t}$} \\
\hline & (1) & (2) & (3) & (4) & (5) & (6) & (7) & $(8)$ & (9) & $(10)$ & (11) & (12) \\
\hline Capital Ratio*Softer MP*Yield & $\begin{array}{c}0.710^{* * *} \\
(0.338)\end{array}$ & $\begin{array}{c}0.746^{* * *} \\
(0.343)\end{array}$ & $\begin{array}{l}0.638^{*} \\
(0.368)\end{array}$ & $\begin{array}{c}0.979 * * \\
(0.463)\end{array}$ & & & & & & & & \\
\hline Capital Ratio*Softer MP* Long Maturity & & & & & $\begin{array}{l}1.883^{* *} \\
(0.754)\end{array}$ & $\begin{array}{l}1.771^{* *} \\
(0.756)\end{array}$ & $\begin{array}{l}1.517^{*} \\
(0.835)\end{array}$ & $\begin{array}{c}1.620 \\
(1.110)\end{array}$ & & & & \\
\hline Capital Ratio*Softer MP* Haircut & & & & & & & & & $\begin{array}{c}0.369 * * \\
(0.179)\end{array}$ & $\begin{array}{c}0.451^{* *} \\
(0.201)\end{array}$ & $\begin{array}{l}0.418^{*} \\
(0.218)\end{array}$ & $\begin{array}{c}0.696 * * \\
(0.318)\end{array}$ \\
\hline Capital Ratio* Softer MP & $\begin{array}{l}-0.982 \\
(0.629)\end{array}$ & $\begin{array}{c}-1.065^{*} \\
(0.624)\end{array}$ & $\begin{array}{c}-1.042 * \\
(0.596)\end{array}$ & $\begin{array}{l}-1.656 \\
(1.169)\end{array}$ & $\begin{array}{l}-0.840 \\
(0.551)\end{array}$ & $\begin{array}{c}-0.979 * \\
(0.539)\end{array}$ & $\begin{array}{c}-0.920 * \\
(0.526)\end{array}$ & $\begin{array}{c}-0.522 \\
(0.899)\end{array}$ & $\begin{array}{l}-0.147 \\
(0.489)\end{array}$ & $\begin{array}{l}-0.212 \\
(0.465)\end{array}$ & $\begin{array}{l}-0.235 \\
(0.477)\end{array}$ & $\begin{array}{c}0.287 \\
(0.670)\end{array}$ \\
\hline Capital Ratio*Yield & $\begin{array}{l}-0.054 \\
(0.140)\end{array}$ & $\begin{array}{l}-0.113 \\
(0.138)\end{array}$ & $\begin{array}{l}-0.098 \\
(0.143)\end{array}$ & $\begin{array}{l}0.0590 \\
(0.225)\end{array}$ & & & & & & & & \\
\hline Capital Ratio*Long Maturity & & & & & $\begin{array}{l}-0.377 \\
(0.436)\end{array}$ & $\begin{array}{c}-0.609 \\
(0.417)\end{array}$ & $\begin{array}{c}-0.604 \\
(0.417)\end{array}$ & $\begin{array}{l}-1.157 \\
(0.889)\end{array}$ & & & & \\
\hline Capital Ratio*Haircut & & & & & & & & & $\begin{array}{l}-0.128 \\
(0.110)\end{array}$ & $\begin{array}{l}-0.127 \\
(0.120)\end{array}$ & $\begin{array}{c}-0.170 \\
(0.123)\end{array}$ & $\begin{array}{c}-0.312 \\
(0.194)\end{array}$ \\
\hline Bank Controls & Yes & Yes & Yes & Yes & Yes & Yes & Yes & Yes & Yes & Yes & Yes & Yes \\
\hline Time Fixed Effects & Yes & Yes & - & - & Yes & Yes & - & - & Yes & Yes & - & - \\
\hline Security Fixed Effects & No & Yes & - & - & No & Yes & - & - & No & Yes & - & - \\
\hline Security*Time Fixed Effects & No & No & Yes & Yes & No & No & Yes & Yes & No & No & Yes & Yes \\
\hline Security*Bank Fixed Effects & No & No & No & Yes & No & No & No & Yes & No & No & No & Yes \\
\hline Observations & 79250 & 79249 & 79227 & 78342 & 79070 & 79069 & 79048 & 78185 & 76565 & 76564 & 76550 & 75661 \\
\hline
\end{tabular}

The table shows regressions of the trading of security $s$ by bank $b$ at time $t$, as a function of a set of macroeconomic, security and bank variables at time $t-1$. Bank controls include capital ratio, interbank, liquidity ratio, bad loans/total assets and size. In this table, the variable Softer MP is the Total Assets of the ECB minus autonomous factors divided by the Italian GDP. The sample period starts in September 2008. The analysis is confined to the sub-sample of Italian government bonds. See Appendix for exact definitions of variables and Section 2 for empirical strategy and data. We always include the lower level of interactions or standalone variables, unless they are absorbed by fixed effects. Fixed effects are either included ("Yes"), not included ("No") or spanned by another set of effects ("-"). Standard errors are double-clustered at bank and security-time level and are reported in parentheses. *** $\mathrm{p}<0.01, * * \mathrm{p}<0.05, * \mathrm{p}<0.1$. 
Table 5: Risk Bearing Capacity? Held to Maturity versus Trading Book and Available for Sale Portfolios

\begin{tabular}{|c|c|c|c|c|c|c|c|c|}
\hline \multirow[t]{3}{*}{ Dependent Variable: } & \multicolumn{8}{|c|}{ Trading $_{s, b, t}$} \\
\hline & \multicolumn{4}{|c|}{ Held to Maturity } & \multicolumn{4}{|c|}{ Other Portfolios (Trading book and Available for Sale) } \\
\hline & (1) & (2) & (3) & (4) & (5) & (6) & (7) & (8) \\
\hline \multirow[t]{2}{*}{ Capital Ratio*Softer MP *Yield } & -0.033 & -0.086 & -0.359 & -0.286 & $0.342 * *$ & $0.359^{* * * *}$ & $0.369^{* *}$ & $0.454 * *$ \\
\hline & $(0.144)$ & $(0.189)$ & $(0.465)$ & $(0.626)$ & $(0.148)$ & $(0.132)$ & $(0.155)$ & $(0.212)$ \\
\hline \multirow[t]{2}{*}{ Capital Ratio* Softer MP } & $-1.419 * * *$ & $-0.649 *$ & $-1.093^{*}$ & 0.439 & $-0.816^{* *}$ & $-0.848 * *$ & $-0.745^{* *}$ & $-1.626 * * *$ \\
\hline & $(0.402)$ & $(0.380)$ & $(0.599)$ & (1.106) & $(0.398)$ & $(0.372)$ & $(0.367)$ & $(0.609)$ \\
\hline \multirow[t]{2}{*}{ Capital Ratio*Yield } & 0.154 & 0.013 & 0.246 & -0.260 & 0.017 & 0.015 & -0.004 & 0.183 \\
\hline & $(0.101)$ & $(0.135)$ & $(0.259)$ & $(0.397)$ & $(0.049)$ & $(0.048)$ & $(0.066)$ & $(0.118)$ \\
\hline Bank Controls & Yes & Yes & Yes & Yes & Yes & Yes & Yes & Yes \\
\hline Time Fixed Effects & Yes & Yes & - & - & Yes & Yes & - & - \\
\hline Security Fixed Effects & No & Yes & - & - & No & Yes & - & - \\
\hline Security*Time Fixed Effects & No & No & Yes & Yes & No & No & Yes & Yes \\
\hline Security*Bank Fixed Effects & No & No & No & Yes & No & No & No & Yes \\
\hline Observations & 14563 & 14559 & 7920 & 7905 & 208970 & 208955 & 207794 & 206880 \\
\hline
\end{tabular}

The table shows regressions of trading of security $s$ by bank $b$ at time $t$, as a function of a set of macroeconomic, security and bank variables at time $t-1$. Bank controls include capital ratio, interbank, liquidity ratio, bad loans/total assets and size. In this table, the variable Softer MP is the Total Assets of the ECB minus autonomous factors divided by the Italian GDP. The sample period starts in September 2008. In this table we split the sample between Held to Maturity (columns 1-4) and Other (Trading Book and Available for Sale) Portfolios (columns 5-8). See Appendix for exact definitions of variables and Section 2 for empirical strategy and data. We always include the lower level Available for Sale) Portfolios (columns 5-8). See Appendix for exact definitions of variables and Section 2 for empirical strategy and data. We always include the lower leve
of interactions or standalone variables, unless they are absorbed by fixed effects. Fixed effects are either included ("Yes"), not included ("No") or spanned by another set of of interactions or standalone variables, unless they are absorbed by fixed effects. Fixed effects are either included ("Yes"), not included ("No")
effects ("-"). Standard errors are double-clustered at bank and security-time level and are reported in parentheses. ${ }^{* * *} \mathrm{p}<0.01,{ }^{* *} \mathrm{p}<0.05,{ }^{*} \mathrm{p}<0.1$. 
Table 6: Monetary Policy, Bank Capital and Reach-for-Yield in the Security Portfolio in Normal Times

\begin{tabular}{|c|c|c|c|c|c|c|c|c|c|c|c|c|}
\hline \multirow[t]{2}{*}{ Dependent Variable: } & \multicolumn{12}{|c|}{ Trading $_{s, b, t}$} \\
\hline & (1) & (2) & (3) & (4) & (5) & (6) & (7) & (8) & (9) & (10) & (11) & (12) \\
\hline Softer MP & $\begin{array}{c}1.341 * * * \\
(0.224)\end{array}$ & $\begin{array}{c}1.274 * * * \\
(0.234)\end{array}$ & $\begin{array}{c}1.480 * * * \\
(0.250)\end{array}$ & & & & & & $\begin{array}{c}1.258^{* * * * *} \\
(0.270)\end{array}$ & & & \\
\hline Capital Ratio* Softer MP & & & & $\begin{array}{c}-0.081 \\
(0.0972)\end{array}$ & $\begin{array}{l}-0.098 \\
(0.105)\end{array}$ & $\begin{array}{c}0.190 \\
(0.137)\end{array}$ & $\begin{array}{c}0.533 \\
(0.365)\end{array}$ & $\begin{array}{c}0.019 \\
(0.089)\end{array}$ & $\begin{array}{c}0.047 \\
(0.0995)\end{array}$ & $\begin{array}{c}0.086 \\
(0.125)\end{array}$ & $\begin{array}{c}0.047 \\
(0.0982)\end{array}$ & $\begin{array}{c}0.078 \\
(0.104)\end{array}$ \\
\hline Capital Ratio* Softer MP*Yield & & & & & & & & & $\begin{array}{l}0.0953^{*} \\
(0.0550)\end{array}$ & $\begin{array}{c}0.062 \\
(0.097)\end{array}$ & $\begin{array}{c}0.0839 \\
(0.0532)\end{array}$ & $\begin{array}{c}0.103^{*} \\
(0.0542)\end{array}$ \\
\hline Capital Ratio*Yield & & & & $\begin{array}{c}0.0725 \\
(0.0887)\end{array}$ & $\begin{array}{c}0.064 \\
(0.089)\end{array}$ & $\begin{array}{c}0.023 \\
(0.048)\end{array}$ & $\begin{array}{l}-0.045 \\
(0.368)\end{array}$ & $\begin{array}{l}0.0733 \\
(0.137)\end{array}$ & $\begin{array}{c}0.100 \\
(0.0989)\end{array}$ & $\begin{array}{c}0.108 \\
(0.160)\end{array}$ & $\begin{array}{l}0.0694 \\
(0.101)\end{array}$ & $\begin{array}{c}0.0653 \\
(0.0894)\end{array}$ \\
\hline Softer MP *Yield & & & & $\begin{array}{l}-0.0586 \\
(0.105) \\
\end{array}$ & $\begin{array}{c}0.023 \\
(0.109)\end{array}$ & $\begin{array}{c}0.062 \\
(0.115)\end{array}$ & $\begin{array}{c}-2.492^{* * *} \\
(1.157) \\
\end{array}$ & $\begin{array}{c}0.201 \\
(0.294)\end{array}$ & $\begin{array}{l}-0.0403 \\
(0.122) \\
\end{array}$ & $\begin{array}{c}0.205 \\
(0.294)\end{array}$ & & \\
\hline Macro Controls & No & Yes & Yes & - & - & - & - & - & - & - & - & - \\
\hline Bank Controls & No & Yes & Yes & Yes & Yes & Yes & Yes & Yes & Yes & Yes & Yes & Yes \\
\hline Time Fixed Effects & No & No & No & Yes & Yes & Yes & Yes & - & No & - & - & - \\
\hline Security Fixed Effects & No & No & Yes & No & No & No & No & No & No & No & - & - \\
\hline Bank Fixed Effects & No & No & No & No & No & No & No & No & No & No & No & Yes \\
\hline Rating*Maturity*Time Fixed Effects & No & No & No & No & No & No & No & Yes & No & Yes & - & - \\
\hline Security*Time Fixed Effects & No & No & No & No & No & No & No & No & No & No & Yes & Yes \\
\hline Observations & 334887 & 334887 & 334887 & 334887 & 329088 & 71850 & 12296 & 194680 & 334887 & 194680 & 334887 & 334887 \\
\hline
\end{tabular}

The table shows regressions of trading of security $s$ by bank $b$ at time $t$, as a function of a set of macroeconomic, security and bank variables at time $t-1$. Macro controls include changes in Italian unemployment and inflation. Bank controls include capital ratio, interbank, liquidity ratio, bad loans/total assets and size. In this table, the variable $S o f t e r ~ M P$ is the Taylor-rule residuals multiplied by $(-1)$. The sample period is up to August 2008. In column 5 we restrict the sample to securities which are different from Italian non-financial corporation bonds. In column 6 we restrict the sample to $(-1)$. The sample period is up to August 2008. In column 5 we restrict the sample to securities which are different from Italian non-financial corporation bonds. In column 6 we restrict the sample to
securities which are different from Italian government bonds. In column 7 we restrict the sample to securities issued outside Italy. See Appendix for exact definitions of variables and Section 2 for securities which are different from Italian government bonds. In column 7 we restrict the sample to securities issued outside Italy. See Appendix for exact definitions of variables and Section 2 for
empirical strategy and data. We always include the lower level of interactions or standalone variables, unless they are absorbed by fixed effects. Fixed effects are either included ("Yes"), not included ("No") or spanned by another set of effects ("-"). Standard errors are double-clustered at bank and security-time level, and are reported in parentheses. *** $\mathrm{p}<0.01$, ** $\mathrm{p}<0.05$, * $\mathrm{p}<0.1$. 
Table 7: Monetary policy, Bank Capital and Reach-for-Yield in the Loan Portfolio

\begin{tabular}{|c|c|c|c|c|c|c|c|c|}
\hline \multirow[t]{3}{*}{ Dependent Variable: } & \multicolumn{8}{|c|}{ Granting a Loan Application ${ }_{\mathrm{i}, \mathrm{b}, \mathrm{t}}$} \\
\hline & \multicolumn{4}{|c|}{ Crisis times } & \multicolumn{4}{|c|}{ Normal times } \\
\hline & (1) & (2) & (3) & (4) & (5) & (6) & (7) & (8) \\
\hline Softer MP & $\begin{array}{l}-1.311 \\
(1.304)\end{array}$ & & & & $\begin{array}{l}-0.127 \\
(0.305)\end{array}$ & & & \\
\hline Capital Ratio* Softer MP & $\begin{array}{l}1.003^{*} \\
(0.567)\end{array}$ & $\begin{array}{l}0.902 * \\
(0.473)\end{array}$ & $\begin{array}{c}1.187 * * \\
(0.571)\end{array}$ & & $\begin{array}{c}-0.0926 \\
(0.160)\end{array}$ & $\begin{array}{c}-0.182 \\
(0.111)\end{array}$ & $\begin{array}{l}-0.086 \\
(0.115)\end{array}$ & \\
\hline Capital Ratio* Softer MP *Firm High Risk & $\begin{array}{l}-0.849 \\
(0.701)\end{array}$ & $\begin{array}{l}-0.362 \\
(0.554)\end{array}$ & $\begin{array}{l}-0.486 \\
(0.594)\end{array}$ & & $\begin{array}{l}0.0944 \\
(0.102)\end{array}$ & $\begin{array}{c}0.131 \\
(0.099)\end{array}$ & $\begin{array}{c}0.012 \\
(0.114)\end{array}$ & \\
\hline Capital Ratio* Softer MP* Loan Yield & & & & $\begin{array}{c}-0.0671 \\
(0.351)\end{array}$ & & & & $\begin{array}{c}-0.082 * * * \\
(0.035)\end{array}$ \\
\hline Capital Ratio*Firm High Risk & $\begin{array}{c}0.672 * * \\
(0.324)\end{array}$ & $\begin{array}{c}0.640 * * \\
(0.262)\end{array}$ & $\begin{array}{c}0.428 \\
(0.290)\end{array}$ & & $\begin{array}{l}0.0263 \\
(0.151)\end{array}$ & $\begin{array}{l}0.0696 \\
(0.108)\end{array}$ & $\begin{array}{c}0.111 \\
(0.134)\end{array}$ & \\
\hline Capital Ratio*Loan Yield & & & & $\begin{array}{l}0.0391 \\
(15.76)\end{array}$ & & & & $\begin{array}{c}-0.063 \\
(3.872) \\
\end{array}$ \\
\hline Macro controls & Yes & - & - & - & Yes & - & - & - \\
\hline BankControls & Yes & Yes & Yes & Yes & Yes & Yes & Yes & Yes \\
\hline Firm Fixed Effects & Yes & - & - & - & Yes & - & - & - \\
\hline Firm*Time Fixed Effects & No & Yes & Yes & Yes & No & Yes & Yes & Yes \\
\hline Bank Fixed Effects & Yes & Yes & Yes & - & Yes & Yes & Yes & - \\
\hline Bank*Time Fixed Effects & No & No & No & Yes & No & No & No & Yes \\
\hline Observations & 377441 & 377441 & 238805 & 20830 & 746128 & 746128 & 529085 & 47951 \\
\hline
\end{tabular}

The table shows a set of linear probability model regressions of the probability of a loan application being granted by bank $b$ to firm $i$ over the quarter starting in month $t$, when the application was posted, as a function of macroeconomic, bank and firm variables at time $t$ - 1 . Macro controls include changes in Italian unemployment and inflation. Bank controls include capital ratio, interbank, liquidity ratio, bad loans/total assets and size. In this table the variable Softer MP is the Total Assets of the ECB minus autonomous factors divided by the Italian GDP in the first four columns (Crisis times- sample period starts in September 2008) and the Taylor-rule residuals multiplied by (-1) in the last four columns (Normal times- sample period is up to August 2008). In column 3 and 7 we restrict the sample to
the firms with z-score between 5 and 8 . See Appendix for exact definitions of variables and Section 2 for empirical strategy and data. We always include the lower level firms with Z-score between 5 and 8 . See Appendix for exact definitions of variables and Section 2 for empirical strategy and data. We always include the lower level
of interactions or standalone variables, unless they are absorbed by fixed effects. Fixed effects are either included ("Yes"), not included ("No") or spanned by another set of effects ("-"). Standard errors are double- clustered at the bank and firm-time level, and are reported in parentheses. *** $\mathrm{p}<0.01,{ }^{* *} \mathrm{p}<0.05,{ }^{*} \mathrm{p}<0.1$. 
Table 8: Unconventional Monetary policy, Bank Capital and Firm Real Effects

\begin{tabular}{|c|c|c|c|c|c|c|}
\hline Dependent Variable: & $\begin{array}{c}\Delta \text { Log } \\
\text { (Credit) } \\
(1)\end{array}$ & $\begin{array}{c}\text { Investment } \\
\text { Rate } \\
\text { (3) }\end{array}$ & $\begin{array}{c}\text { Investment } \\
\text { Rate } \\
\text { (no adjust.) } \\
(2)\end{array}$ & $\begin{array}{l}\text { Investment } \\
\text { Rate } \\
\text { (flow) } \\
(4)\end{array}$ & $\begin{array}{c}\Delta \log (\text { Wage } \\
\text { bill) } \\
\text { (5) }\end{array}$ & $\Delta \log ($ Sales) \\
\hline Weighted Capital Ratio*Softer MP & $\begin{array}{l}2.900 * * \\
(1.360)\end{array}$ & $\begin{array}{l}1.765 * * \\
(0.722)\end{array}$ & $\begin{array}{c}2.579 * * * \\
(0.970)\end{array}$ & $\begin{array}{l}1.921 * * \\
(0.948)\end{array}$ & $\begin{array}{l}0.824 * \\
(0.499)\end{array}$ & $\begin{array}{l}1.180 * * \\
(0.558)\end{array}$ \\
\hline Weighted Capital Ratio & $\begin{array}{l}1.190 * * \\
(0.460)\end{array}$ & $\begin{array}{c}0.209 \\
(0.370)\end{array}$ & $\begin{array}{c}0.188 \\
(0.456)\end{array}$ & $\begin{array}{l}-0.339 \\
(0.442)\end{array}$ & $\begin{array}{l}0.0351 \\
(0.201)\end{array}$ & $\begin{array}{c}0.220 \\
(0.226)\end{array}$ \\
\hline Firm Expected Demand & $\begin{array}{c}0.150 * * * \\
(0.032)\end{array}$ & $\begin{array}{l}0.101 * * \\
(0.0416)\end{array}$ & $\begin{array}{l}0.118 * * \\
(0.0472)\end{array}$ & $\begin{array}{c}0.141 * * * \\
(0.0346)\end{array}$ & $\begin{array}{c}0.373 * * * \\
(0.0173)\end{array}$ & $\begin{array}{c}0.825^{* * * *} \\
(0.027)\end{array}$ \\
\hline Firm ROA & $\begin{array}{c}0.807 * * * \\
(0.084)\end{array}$ & $\begin{array}{c}0.350 * * * \\
(0.119)\end{array}$ & $\begin{array}{c}0.164 \\
(0.136)\end{array}$ & $\begin{array}{l}0.0517 \\
(0.101)\end{array}$ & $\begin{array}{c}0.501 * * * \\
(0.0417)\end{array}$ & $\begin{array}{c}0.389 * * * \\
(0.062)\end{array}$ \\
\hline Firm High Risk & $\begin{array}{c}-10.200 * * * \\
(1.370)\end{array}$ & $\begin{array}{l}-0.751 \\
(1.334)\end{array}$ & $\begin{array}{l}-0.949 \\
(1.539)\end{array}$ & $\begin{array}{l}-0.705 \\
(1.318)\end{array}$ & $\begin{array}{c}-2.810 * * * \\
(0.634)\end{array}$ & $\begin{array}{c}-3.190 * * * \\
(0.889)\end{array}$ \\
\hline Firm Size & $\begin{array}{c}-0.845 * * \\
(0.331)\end{array}$ & $\begin{array}{c}-1.221 * * * \\
(0.363)\end{array}$ & $\begin{array}{c}-1.850 * * * \\
(0.418)\end{array}$ & $\begin{array}{c}-3.362 * * * \\
(0.405)\end{array}$ & $\begin{array}{c}0.369 * * * \\
(0.122)\end{array}$ & $\begin{array}{c}-0.285^{*} \\
(0.165)\end{array}$ \\
\hline $\begin{array}{l}\text { Industry*Time FE } \\
\text { Province*Time FE } \\
\text { Observations }\end{array}$ & $\begin{array}{c}\text { Yes } \\
\text { Yes } \\
11082\end{array}$ & $\begin{array}{c}\text { Yes } \\
\text { Yes } \\
11114\end{array}$ & $\begin{array}{c}\text { Yes } \\
\text { Yes } \\
11111\end{array}$ & $\begin{array}{c}\text { Yes } \\
\text { Yes } \\
11127\end{array}$ & $\begin{array}{c}\text { Yes } \\
\text { Yes } \\
11105\end{array}$ & $\begin{array}{c}\text { Yes } \\
\text { Yes } \\
11113\end{array}$ \\
\hline
\end{tabular}

The table shows OLS regressions of the change in log credit (column 1), investment rate (columns 2- 4), change in log of wage bill (column 5 ) and change in $\log$ of sales (column 6 ) at a firm level at time $t$, on a set of macroeconomic and firm variables at time $t$ - 1 . In this table, the variable Softer MP is the Total Assets of the ECB minus autonomous factors divided by the Italian GDP. See Appendix for exact definitions of variables and Section 2 for empirical strategy and data. Standard errors are clustered at firm level and are reported in parentheses. *** $\mathrm{p}<0.01, * * \mathrm{p}<0.05, * \mathrm{p}<0.1$. 
APPENDIX

Table A1: Description of Variables

\begin{tabular}{|c|c|c|}
\hline Variable & Description & Source \\
\hline \multicolumn{3}{|l|}{ Security Holdings } \\
\hline Trading & $\begin{array}{l}\text { Net buys of security } s \text {, by bank } b \text { during the month } t \text {. This growth rate is } \\
\text { symmetric around } 0 \text { and it lays in the closed interval }[-200,200] \text { with } \\
\text { final sales (initial purchases) corresponding to the left (right) endpoint } \\
\text { (Davis and Haltiwanger, 1992) }\end{array}$ & Security Register \\
\hline Log (Holdings) & $\begin{array}{l}\text { The difference between the logarithm of }(1+\text { holdings of security } s \text {, by } \\
\text { bank } b \text { at time } t) \text { and the logarithm of }(1+\text { holdings of security } s \text {, by } \\
\text { bank } b \text { at time } t-1)\end{array}$ & Security Register \\
\hline \multicolumn{3}{|l|}{ Loan applications } \\
\hline Granting a Loan Application & $\begin{array}{l}\text { Dummy equal to } 1 \text { if a loan application is granted to firm } i \text { by bank } b \\
\text { over the quarter starting in month } t \text {, when the application was } \\
\text { posted(multiplied by 100) }\end{array}$ & Central Credit Register \\
\hline \multicolumn{3}{|l|}{ Firm-level Outcomes } \\
\hline$\Delta \log ($ Credit $)$ & Changes in the log of total credit at firm level & Central Credit Register \\
\hline Investment Rate & $\begin{array}{l}\text { Changes in adjusted total assets at time } t \text { divided by adjusted total } \\
\text { assets at } t-1 \text {, (where adjusted total assets is equal to total assets - fair } \\
\text { value revaluation). We use also two additional measures of investment } \\
\text { rate. The second measure is the same as the first one but without } \\
\text { adjusting for the fair value revaluation. In the third measure the } \\
\text { numerator is a flow measure of investments from the income statement. }\end{array}$ & Cerved \\
\hline$\Delta \log ($ Wage bill) & Changes in the log of wage bill & Cerved \\
\hline$\Delta$ Log (Sales) & Changes in the log of sales (net revenues) & Cerved \\
\hline
\end{tabular}

Monetary Policy Proxies

Softer MP (normal times)

Taylor-rule residuals obtained by regressing EONIA (the overnight interest rate for the EURO area) on Italian GDP growth and inflation (Taylor, 2008)

Softer MP (crisis times)

Total assets of the ECB balance sheet minus autonomous factors divided by the nominal Italian GDP, in percentage

Security Characteristics

Yield

Yield to redemption ("RY" in Datastream) minus EONIA (the overnight interest rate for the EURO area), in percentage

Ratings

Long Maturity Ratings issued by Moodys

Own Calculations on OECD

data

ECB and Bank of Italy

Datastream

Factset

Dummy equal to 1 if the residual maturity is larger than the 75th Factset percentile of the distribution

Haircut

Haircut applied by the ECB for eligible marketable assets, in ECB percentage

Firm Characteristics

Loan Yield

The largest interest rate paid by the firm in the pre-exiting credit relations minus EONIA (the overnight interest rate for the EURO area), in percentage

Firm High Risk

This is a dummy equal to 1 if the $\mathrm{z}$-score is larger or equal to 7 . With a $\mathrm{z}$-score between 7 and 9 the company is defined as high risk (Rodano et al., 2015). The z-score measures the likelihood of a firm's default within one year. The score takes values between 1 (least likely to default) and 9 (most likely to default)

Weighted Capital Ratio

Weighted average of the capital ratios of the banks the firm is exposed

to (the weights are the shares of credit)

Firm ROA

Firm Return on Assets

Log of firm total assets

Firm Size

Firm expected demand growth

Firm Expected Demand

Bank Characteristics

Capital Ratio

Excess Capital

Net Worth

Interbank
Equity (shares subscribed, book value of equity plus retained earnings) divided by total assets, in percentage

Capital in excess of the regulatory requirement, divided by assets, in percentage

Capital ratio plus ROA, in percentage

Ratio of total borrowing from other banks to total assets, inclusive of deposits and repos from other banks, exclusive of deposits from the $\mathrm{ECB}$ or other national central banks, in percentage
Central Credit Register

Cerved

Central Credit Register

Cerved

Cerved

Survey of Industrial and Service Firms

Supervisory Reports

Supervisory Reports

Supervisory Reports

Supervisory Reports 
Liquidity

Size

Bad Loans/Total Assets

Securities/Loans

Macro Controls

$\Delta \mathrm{CPI}$

$\Delta$ Unemployment
Sum of cash holdings and sovereign bonds divided by total assets, in percentage

Logarithm of total assets

Percentage of bad and non-performing loans ('incagli' and Supervisory Reports 'sofferenze') out of total bank assets, in percentage

Ratio of securities holdings to loans (both to firms and households)

Monthly change in the Italian Consumer Price Index

Bank of Italy

Monthly change in the Italian unemployment rate.
Supervisory Reports

Supervisory Reports

Supervisory Reports

The table describes the main dependent and control variables we use in the paper. 
Table A2: Descriptive Statistics in Normal Times

\begin{tabular}{|c|c|c|c|c|c|}
\hline & Mean & St.Dev. & Median & $\mathrm{p} 25$ & p75 \\
\hline \multicolumn{6}{|l|}{ Security Holdings } \\
\hline Trading & 1.551 & 81.281 & 0.032 & -2.053 & 5.993 \\
\hline$\Delta$ Log (Holdings) & 6.797 & 233.311 & 0.032 & -2.055 & 5.989 \\
\hline \multicolumn{6}{|l|}{ Monetary Policy Proxy } \\
\hline Softer MP & 0.759 & 0.927 & 0.584 & -0.031 & 1.388 \\
\hline \multicolumn{6}{|l|}{ Bank Characteristics } \\
\hline Size & 9.571 & 1.734 & 9.499 & 7.865 & 10.673 \\
\hline Capital Ratio & 7.848 & 2.302 & 7.452 & 6.300 & 9.035 \\
\hline Excess capital & 2.497 & 2.024 & 1.867 & 1.156 & 3.165 \\
\hline Net Worth & 8.391 & 2.389 & 7.982 & 6.725 & 9.604 \\
\hline Liquidity Ratio & 10.361 & 6.938 & 8.602 & 5.220 & 13.564 \\
\hline Interbank & 13.165 & 9.997 & 11.95 & 6.330 & 17.104 \\
\hline Bad Loans/ Total Assets & 2.830 & 1.958 & 2.344 & 1.441 & 3.795 \\
\hline \multicolumn{6}{|l|}{ Security Characteristics } \\
\hline Yield & 0.873 & 1.429 & 0.575 & 0.123 & 1.336 \\
\hline Yield (Italian Gov.) & 0.682 & 1.020 & 0.444 & 0.077 & 1.052 \\
\hline Yield (Non Italian Gov.) & 1.572 & 2.254 & 1.261 & 0.571 & 2.235 \\
\hline Residual Maturity (months) & 53.933 & 74.767 & 29.267 & 10.633 & 58.300 \\
\hline Rating $=\mathrm{AAA}$ & 0.012 & 0.107 & 0 & 0 & 0 \\
\hline Rating $>=\mathrm{A}$ & 0.910 & 0.286 & 1 & 1 & 1 \\
\hline \multicolumn{6}{|l|}{ Macro controls } \\
\hline$\Delta \mathrm{CPI}$ & 0.166 & 0.108 & 0.200 & 0.100 & 0.200 \\
\hline$\Delta$ Unemployment & -0.050 & 0.133 & -0.099 & -0.100 & 0.000 \\
\hline \multicolumn{6}{|l|}{ Loans } \\
\hline \multicolumn{6}{|l|}{ Granting at Least One Loan } \\
\hline Application (x100) & 39.099 & 48.797 & 0 & 0 & 100 \\
\hline \multicolumn{6}{|l|}{ Firms } \\
\hline Firm High Risk & 0.412 & 0.492 & 0 & 0 & 1 \\
\hline Loan Yield & 7.364 & 4.906 & 6.519 & 4.540 & 8.988 \\
\hline
\end{tabular}

The table shows descriptive statistics of the main variables employed in our analysis in normal times (up to August 2008). 
Table A3: Unconventional Monetary policy, Bank Capital and the Choice Between Securities and Loans in Crisis Times: Aggregate Evidence

\begin{tabular}{|c|c|c|c|c|c|c|}
\hline \multirow[t]{3}{*}{ Dependent Variable } & \multicolumn{6}{|c|}{ Securities/Loans $_{\mathrm{b}, \mathrm{t}}$} \\
\hline & & OLS & & & WLS & \\
\hline & (1) & $(2)$ & (4) & (5) & (6) & $(8)$ \\
\hline \multirow[t]{2}{*}{ Softer MP } & 6.050 & 5.298 & 4.495 & 5.619 & 5.198 & 4.561 \\
\hline & $(8.993)$ & $(8.265)$ & $(3.080)$ & $(8.469)$ & $(8.185)$ & $(3.219)$ \\
\hline \multirow[t]{2}{*}{ Capital Ratio* Softer MP } & $-2.335 * *$ & $-2.407 * *$ & $-2.250^{* *}$ & $-2.295 * *$ & $-2.346 * *$ & $-2.184 * *$ \\
\hline & $(0.921)$ & $(0.975)$ & $(0.990)$ & $(0.903)$ & $(0.970)$ & $(0.954)$ \\
\hline \multirow[t]{2}{*}{ Size*Softer MP } & & & 1.214 & & & 1.192 \\
\hline & & & $(1.720)$ & & & $(1.430)$ \\
\hline Macro Controls & No & Yes & Yes & No & Yes & Yes \\
\hline Bank controls & Yes & Yes & Yes & Yes & Yes & Yes \\
\hline Bank Fixed Effects & Yes & Yes & Yes & Yes & Yes & Yes \\
\hline Observations & 845 & 845 & 845 & 845 & 845 & 845 \\
\hline
\end{tabular}

The table shows regressions of the ratio between securities and loans by bank $b$ at time $t$, as a function of a set of macroeconomic and bank variables at time $t-1$. Macro controls include changes in Italian unemployment and inflation. Bank controls include capital ratio, interbank, liquidity ratio, bad loans/total assets and size. In this table, the variable Softer $M P$ is the Total Assets of the ECB minus autonomous factors divided by the Italian GDP. The sample period starts in 2008 and data are recorded at the end of each semester. The first three columns report OLS estimates. The last three columns report WLS estimates where the weight is the size of the bank. See Appendix for exact definitions of variables and Section 2 for empirical strategy and data. Standard errors are double-clustered at bank and time level and are reported in parentheses. $* * * \mathrm{p}<0.01, * * \mathrm{p}<0.05, * \mathrm{p}<0.1$ 